Prepared in cooperation with the U.S. Army Corps of Engineers

Total Dissolved Gas and Water Temperature in the Lower Columbia River, Oregon and Washington, Water Year 2013: Quality-Assurance Data and Comparison to Water-Quality Standards

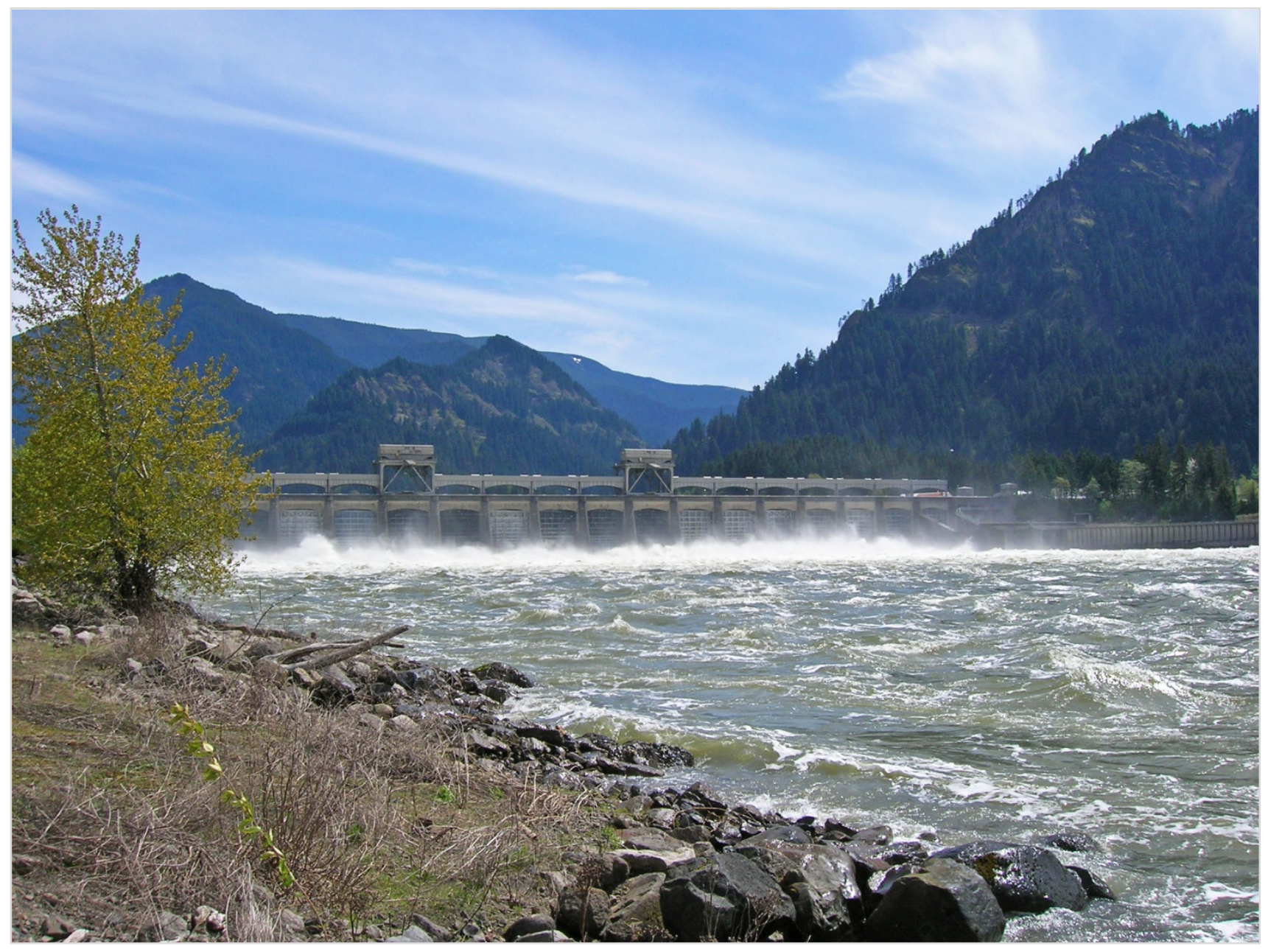

Open-File Report 2013-1281

U.S. Department of the Interior U.S. Geological Survey 
Cover: Bonneville Dam on the Columbia River, viewed from Washington. Flow through the spillway facilitates fish passage downstream, but the extreme turbulence entrains air into the water and increases the concentration of dissolved nitrogen to levels that can be unhealthy for the fish. The U.S. Geological Survey monitors total-dissolvedgas concentration to help the U.S. Army Corps of Engineers maintain levels that enable fish survival. (Photograph by Heather Bragg, USGS, April 20, 2006.) 


\section{Total Dissolved Gas and Water Temperature in the Lower Columbia River, Oregon and Washington, Water Year 2013: Quality-Assurance Data and Comparison to Water-Quality Standards}

By Heather M. Bragg and Matthew W. Johnston

Prepared in cooperation with the U.S. Army Corps of Engineers

Open-File Report 2013-1281

U.S. Department of the Interior

U.S. Geological Survey 


\section{U.S. Department of the Interior \\ SALLY JEWELL, Secretary \\ U.S. Geological Survey \\ Suzette M. Kimball, Director}

U.S. Geological Survey, Reston, Virginia: 2014

For more information on the USGS-the Federal source for science about the Earth, its natural and living resources, natural hazards, and the environment, visit http://www.usgs.gov or call 1-888-ASK-USGS.

For an overview of USGS information products, including maps, imagery, and publications, visit $h$ ttp://www.usgs.gov/pubprod

To order this and other USGS information products, visit http://store.usgs.gov

Suggested citation:

Bragg, H.M. and Johnston, M.W., 2014, Total dissolved gas and water temperature in the lower Columbia River, Oregon and Washington, water year 2013: Quality-assurance data and comparison to water-quality standards: U.S. Geological Survey Open-File Report 2013-1281, 27 p., http://dx.doi.org/10.3133/ofr20131281.

ISSN 2331-1258 (online)

Any use of trade, firm, or product names is for descriptive purposes only and does not imply endorsement by the U.S. Government.

Although this information product, for the most part, is in the public domain, it also may contain copyrighted materials as noted in the text. Permission to reproduce copyrighted items must be secured from the copyright owner. 


\section{Contents}

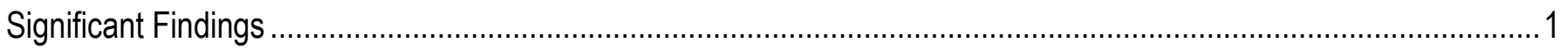

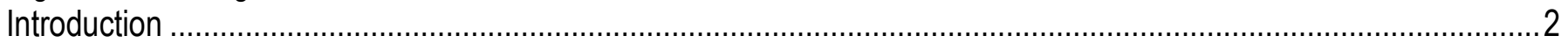

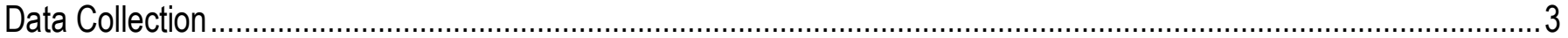

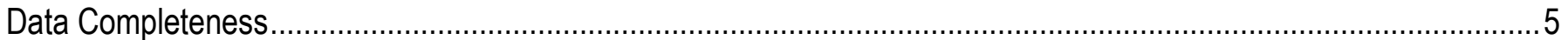

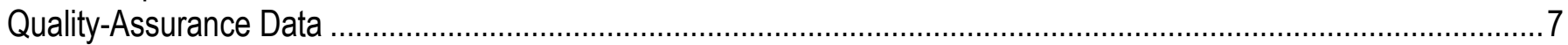

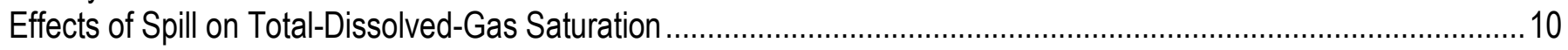

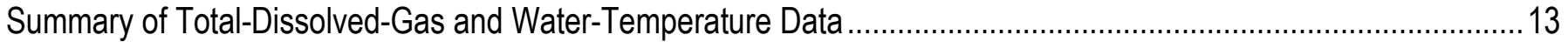

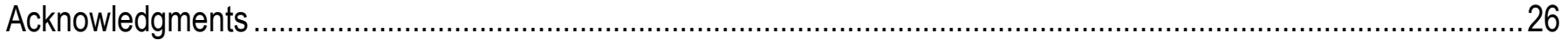

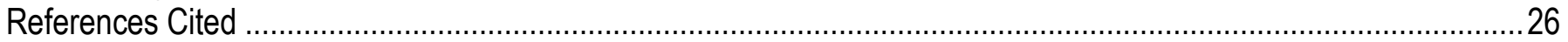

\section{Figures}

Figure 1. Location of U.S. Army Corp of Engineers dams and total-dissolved-gas monitoring stations, lower Columbia River, Oregon and Washington, water year 2013.

Figure 2. Boxplot showing accuracy of total-dissolved-gas sensors in the laboratory after 3 or 4 weeks of field deployment at eight monitoring stations in the lower Columbia River, Oregon and Washington, water year $2013 \ldots . . .8$

Figure 3. Boxplot showing difference between the secondary standard and the field barometers in the field after 3 or 4 weeks of field deployment at eight stations in the lower Columbia River, Oregon and Washington, water year 2013.

Figure 4. Boxplot showing difference between the secondary standard and the field temperature instruments in the field after 3 or 4 weeks of field deployment at eight stations in the lower Columbia River, Oregon and Washington, water year 2013.

Figure 5. Boxplot showing difference between the secondary standard and the field total-dissolved-gas instruments in the field after 3 or 4 weeks of field deployment at eight stations in the lower Columbia River, Oregon and Washington, water year 2013.

Figure 6. Graph showing relation of total-dissolved-gas saturation downstream of John Day Dam and spill from the dam, lower Columbia River, Oregon and Washington, April 1-August 31, 2013.

Figure 7. Graph showing relation of total-dissolved-gas saturation downstream of The Dalles Dam and spill from The Dalles Dam, lower Columbia River, Oregon and Washington, April 1-August 31, 2013.

Figure 8. Graph showing relation of total-dissolved-gas saturation downstream of Bonneville Dam at Cascade Island and spill from Bonneville Dam, lower Columbia River, Oregon and Washington, April 1-August 31, 2013 _...12

Figure 9. Graph showing relation of total-dissolved-gas saturation downstream of Bonneville Dam at Warrendale and spill from Bonneville Dam, lower Columbia River, Oregon and Washington, April 1-August 31, 2013

Figure 10. Boxplot showing distributions of hourly total-dissolved-gas data and Oregon and Washington totaldissolved-gas waivers/criteria adjustments, lower Columbia River, Oregon and Washington, April 1-August 31, 2013.

Figure 11. Graphs showing high 12-hour average of total-dissolved-gas saturation at John Day Dam navigation lock and spill from McNary Dam (76 river miles upstream from John Day Dam), lower Columbia River, Oregon and Washington, April 1-August 31, 2013.

Figure 12. Graphs showing total-dissolved-gas saturation at John Day Dam tailwater and spill from John Day Dam, lower Columbia River, Oregon and Washington, April 1-August 31, 2013.

Figure 13. Graphs showing total-dissolved-gas saturation at The Dalles Dam forebay and spill from John Day Dam, lower Columbia River, Oregon and Washington, April 1-August 31, 2013. 
Figure 14. Graphs showing total-dissolved-gas saturation at The Dalles Dam tailwater and spill from The Dalles Dam, lower Columbia River, Oregon and Washington, April 1-August 31, 2013.

Figure 15. Graphs showing total-dissolved-gas saturation at Bonneville Dam forebay and spill from The Dalles Dam, lower Columbia River, Oregon and Washington, April 1-August 31, 2013.

Figure 16. Graphs showing total-dissolved-gas saturation at Cascade Island and spill from Bonneville Dam, lower Columbia River, Oregon and Washington, April 1-August 31, 2013.

Figure 17. Graphs showing total-dissolved-gas saturation at Warrendale and spill from Bonneville Dam, lower Columbia River, Oregon and Washington, April 1-August 31, 2013.

Figure 18. Graphs showing total-dissolved-gas saturation at Camas and spill from Bonneville Dam, lower Columbia River, Oregon and Washington, April 1-August 31, 2013.

Figure 19. Graph showing water temperature upstream of John Day Dam and downstream of John Day Dam, lower Columbia River, Oregon and Washington, summer 2013.

Figure 20. Graph showing water temperature upstream and downstream of The Dalles Dam, lower Columbia River, Oregon and Washington, summer 2013.

Figure 21. Graph showing water temperature upstream of Bonneville Dam and downstream of Bonneville Dam at Cascade Island, lower Columbia River, Oregon and Washington, summer 2013.

Figure 22. Graph showing water temperature upstream of Bonneville Dam and downstream of Bonneville Dam at Warrendale, lower Columbia River, Oregon and Washington, summer 2013.

Figure 23. Graph showing water temperature downstream of Bonneville Dam at Camas, lower Columbia River, Oregon and Washington, summer 2013.

\section{Tables}

Table 1. Total-dissolved-gas monitoring stations, lower Columbia River, Oregon and Washington, water year 2013

Table 2. Completeness and quality of total-dissolved gas data, lower Columbia River, Oregon and Washington, water year 2013

Table 3. Periods of missing real-time TDG data, lower Columbia River, Oregon and Washington, water year 2013 


\section{Conversion Factors, Datum, and Abbreviations and Acronyms}

\section{Conversion Factors}

\begin{tabular}{lll}
\hline \multicolumn{1}{c}{ Multiply } & \multicolumn{1}{c}{ By } & \multicolumn{1}{c}{ To obtain } \\
\hline cubic foot per second $\left(\mathrm{ft}^{3} / \mathrm{s}\right)$ & 0.02832 & cubic meter per second $\left(\mathrm{m}^{3} / \mathrm{s}\right)$ \\
mile $(\mathrm{mi})$ & 1.609 & kilometer $(\mathrm{km})$ \\
millimeter $(\mathrm{mm})$ & 0.03937 & inch (in.) \\
square mile $\left(\mathrm{mi}^{2}\right)$ & 2.590 & square kilometer $\left(\mathrm{km}^{2}\right)$ \\
\hline
\end{tabular}

Temperature in degrees Celsius $\left({ }^{\circ} \mathrm{C}\right)$ may be converted to degrees Fahrenheit $\left({ }^{\circ} \mathrm{F}\right)$ as follows:

${ }^{\circ} \mathrm{F}=\left(1.8 \mathrm{x}^{\circ} \mathrm{C}\right)+32$.

\section{Datum}

Horizontal coordinate information is referenced to the North American Datum of 1927 (NAD 27).

$\begin{array}{ll}\text { Abbreviations and Acronyms } \\ \text { BON } & \text { Bonneville forebay } \\ \text { CCIW } & \text { Cascade Island } \\ \text { CWMW } & \text { Camas } \\ \text { DCP } & \text { Data-collection platform } \\ \text { GOES } & \text { Geostationary Operational Environmental Satellite } \\ \text { JDY } & \text { John Day navigation lock } \\ \text { JHAW } & \text { John Day Dam tailwater } \\ \text { NIST } & \text { National Institute of Standards and Technology } \\ \text { RM } & \text { River mile } \\ \text { TDA } & \text { The Dalles forebay } \\ \text { TDDO } & \text { The Dalles tailwater } \\ \text { TDG } & \text { Total dissolved gas } \\ \text { USACE } & \text { U.S. Army Corps of Engineers } \\ \text { USGS } & \text { U.S. Geological Survey } \\ \text { WRNO } & \text { Warrendale }\end{array}$


This page is intentionally blank 


\section{Total Dissolved Gas and Water Temperature in the Lower Columbia River, Oregon and Washington, Water Year 2013: Quality-Assurance Data and Comparison to Water-Quality Standards}

By Heather M. Bragg and Matthew W. Johnston

\section{Significant Findings}

An analysis of total-dissolved-gas (TDG) and water-temperature data collected at eight fixed monitoring stations on the lower Columbia River in Oregon and Washington in water year 2013 indicated the following:

- During the spill season of April-August 2013, the averages of the 12 highest hourly TDG values in a day were periodically greater than 115-percent saturation for the forebay stations (John Day navigation lock, The Dalles forebay, and Bonneville forebay) and the Camas station. The 12 highest average daily values of TDG were also periodically greater than 120-percent saturation at Cascade Island. TDG values at the other tailwater stations (John Day Dam tailwater, The Dalles tailwater, and Warrendale) did not exceed 120 -percent saturation.

- During parts of July, August, and September 2013, hourly water temperatures were greater than 20 degrees Celsius at all eight monitoring stations on the lower Columbia River.
- All of the 98 TDG sensor laboratory checks that were performed after field deployment were within \pm 0.5 -percent saturation of a primary standard.

- After 3-4 weeks of deployment in the river, all but 1 of 85 TDG sensor field checks were within \pm 1.0 -percent saturation of a secondary standard. All but 1 of 87 barometric pressure field checks were within \pm 1 millimeter of mercury of a primary standard, and all 86 water-temperature field checks were within \pm 0.2 degrees Celsius of a secondary standard.

- For the eight monitoring stations, a total of 99.2 percent of the TDG data were received in real time and were within 1-percent saturation of the expected value on the basis of calibration data, replicate quality-control measurements, and comparison to river conditions at adjacent sites. Data completeness for the monitoring stations ranged from 97.7 to 100 percent.

- All quality-assurance and data completeness values exceed the criteria established by the U.S. Army Corps of Engineers TDG monitoring plan. 


\section{Introduction}

The U.S. Army Corps of Engineers (USACE) operates several dams in the lower Columbia River Basin in Oregon and Washington (fig. 1), which encompasses $259,000 \mathrm{mi}^{2}$ of the Pacific Northwest. These dams are multipurpose structures that fulfill regional needs for flood control, navigation, irrigation, recreation, hydropower production, fish and wildlife habitat, water-quality maintenance, and municipal and industrial water supply. When water is released through the spillways of these dams (instead of being routed through the turbines to generate electricity), ambient air is entrained in the water. This results in an increase in the concentration of dissolved gases (referred to here as "total dissolved gas," or "TDG") in the water downstream of the spillways. Concentrations of TDG greater than 110-percent saturation can cause gas-bubble trauma in fish and adversely affect other aquatic organisms (U.S. Environmental Protection Agency, 1986). The USACE regulates streamflow and spill from its dams on the lower Columbia River to minimize the production of excess TDG downstream from the dams, with the additional goal of providing for fish passage through the spillways (rather than through the turbines).

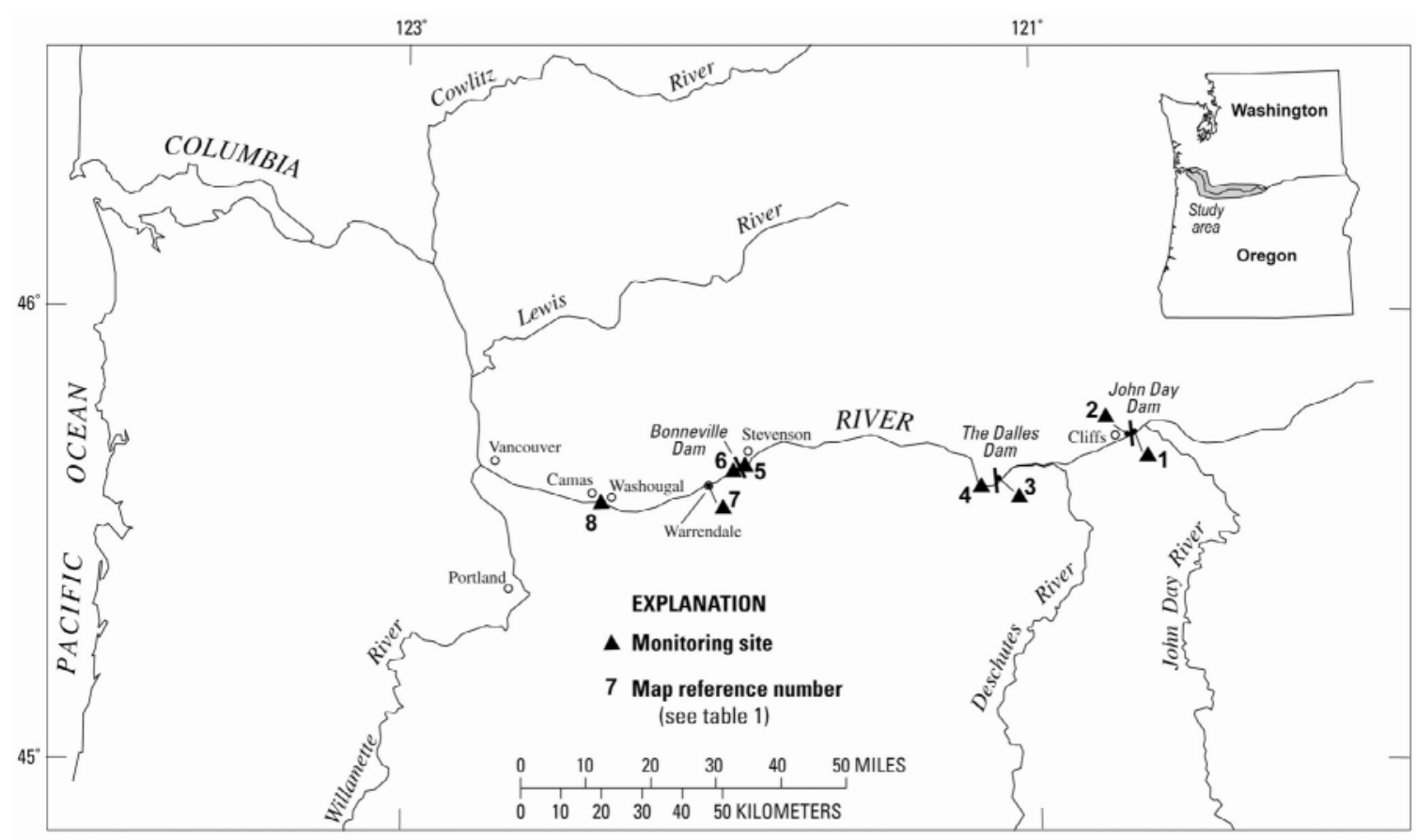

Basemap modified from USGS and other digital data, variable scales. Projection unknown.

Figure 1. Location of U.S. Army Corp of Engineers dams and total-dissolved-gas monitoring stations, lower Columbia River, Oregon and Washington, water year 2013.

Real-time TDG and water-temperature data are vital to the USACE for dam operation and for monitoring compliance with environmental regulations. The data are used by water managers to maintain water-quality conditions that facilitate fish passage and ensure their survival in the lower Columbia River. The U.S. Geological Survey (USGS), in cooperation with the Portland District of the USACE, has collected TDG and related data in the lower Columbia River each year since 1996. The hourly values were stored in the USGS database and in a USACE database (U.S. Army Corps of Engineers, 2013). Those data are available online within an hour of collection time, and the current and historical TDG and watertemperature data can be accessed at 
http://oregon.usgs.gov/projs_dir/pn307.tdg/. The USACE database also includes hourly river discharge and spill data.

Fourteen previous reports, published for water years 1996 and 2000-2012, describe the TDG data, quality-assurance data, and methods of data collection (Tanner and others, 1996; Tanner and Bragg, 2001; Tanner and Johnston, 2001; and Tanner and others, 2002, 2003, 2004, 2005, 2006, 2007, 2008, 2009, 2011, 2012).

This report presents the TDG data and related quality-assurance data that demonstrate the USACE Portland District's compliance with the TDG monitoring plan (U.S. Army Corps of Engineers, 2008). To assure the accuracy and integrity of the data needed for managing and modeling TDG in the lower Columbia River, hourly values were reviewed relative to concurrent field measurements, laboratory sensor calibrations, and inter-site comparisons. All deleted or missing data are explained in detail. The TDG percent saturation and water-temperature data are also compared to relevant water-quality standards.

\section{Data Collection}

Eight monitoring stations were operated on the lower Columbia River, from the navigation lock of the John Day Dam (river mile [RM] 215.7) to Camas, Washington (RM 121.7) (fig. 1, table 1). Data for water year 2013 (October 1, 2012, to September 30,2013) include hourly measurements of TDG pressure, barometric pressure, water temperature, and sensor depth. Four of the stations (John Day Dam navigation lock, The Dalles Dam forebay, Bonneville Dam forebay, and Camas) were operated from March to September 2013, the period that includes the usual time for spill operations from the dams. The site at Cascade Island was damaged on August 29, 2013, and no data were collected during the last 2 days of the spill season. The stations John Day Dam tailwater, The Dalles Dam tailwater, and Warrendale were operated year-round. 
Table 1. Total-dissolved-gas monitoring stations, lower Columbia River, Oregon and Washington, water year 2013

[Map reference number refers to figure 1; USACE, U.S. Army Corps of Engineers; Columbia River mile locations were determined from U.S. Geological Survey (USGS) 7.5-minute topographic maps; stations in this report are referenced by their abbreviated name or USACE station identifier; ${ }^{\circ}$, degree; ', minute;", second; latitude and longitude are referenced to the North American Datum of 1927; River mile is distance from the mouth of the Columbia River.]

\begin{tabular}{|c|c|c|c|c|c|c|c|}
\hline $\begin{array}{l}\text { Map } \\
\text { reference } \\
\text { number }\end{array}$ & $\begin{array}{l}\text { USACE } \\
\text { station } \\
\text { identifier }\end{array}$ & $\begin{array}{l}\text { River } \\
\text { mile }\end{array}$ & $\begin{array}{c}\text { USGS } \\
\text { station number }\end{array}$ & $\begin{array}{l}\text { USGS station name } \\
\text { (and abbreviated station name) }\end{array}$ & Latitude & Longitude & $\begin{array}{l}\text { Period of } \\
\text { record in water } \\
\text { year } 2013\end{array}$ \\
\hline 1 & JDY & 215.7 & 454314120413701 & $\begin{array}{l}\text { Columbia River at John Day navigation lock, } \\
\text { Washington (John Day navigation lock) }\end{array}$ & $45^{\circ} 43^{\prime} 14^{\prime \prime}$ & $120^{\circ} 41^{\prime} 37^{\prime \prime}$ & $\begin{array}{c}03 / 20 / 13- \\
09 / 17 / 13\end{array}$ \\
\hline 2 & JHAW & 214.7 & 454249120423500 & $\begin{array}{l}\text { Columbia River, right bank, near Cliffs, } \\
\text { Washington (John Day tailwater) }\end{array}$ & $45^{\circ} 42^{\prime} 49^{\prime \prime}$ & $120^{\circ} 42^{\prime} 35^{\prime \prime}$ & $\begin{array}{l}10 / 01 / 12- \\
09 / 30 / 13\end{array}$ \\
\hline 3 & TDA & 192.6 & 453712121071200 & $\begin{array}{l}\text { Columbia River at The Dalles Dam forebay, } \\
\text { Washington (The Dalles forebay) }\end{array}$ & $45^{\circ} 37^{\prime} 12^{\prime \prime}$ & $121^{\circ} 07^{\prime} 12^{\prime \prime}$ & $\begin{array}{c}03 / 21 / 13- \\
09 / 18 / 13\end{array}$ \\
\hline 4 & TDDO & 188.9 & 14105700 & $\begin{array}{l}\text { Columbia River at The Dalles, Oregon (The } \\
\text { Dalles tailwater) }\end{array}$ & $45^{\circ} 36^{\prime} 27^{\prime \prime}$ & $121^{\circ} 10^{\prime} 20^{\prime \prime}$ & $\begin{array}{c}10 / 01 / 12- \\
09 / 30 / 13\end{array}$ \\
\hline 5 & BON & 146.1 & 453845121562000 & $\begin{array}{l}\text { Columbia River at Bonneville Dam forebay, } \\
\text { Washington (Bonneville forebay) }\end{array}$ & $45^{\circ} 38^{\prime} 45^{\prime \prime}$ & $121^{\circ} 56^{\prime} 20^{\prime \prime}$ & $\begin{array}{c}03 / 21 / 13- \\
09 / 18 / 13\end{array}$ \\
\hline 6 & CCIW & 145.9 & 453845121564001 & $\begin{array}{l}\text { Columbia River at Cascade Island, Washing- } \\
\text { ton (Cascade Island) }\end{array}$ & $45^{\circ} 38^{\prime} 45^{\prime \prime}$ & $121^{\circ} 56^{\prime} 40^{\prime \prime}$ & $\begin{array}{c}03 / 14 / 13- \\
08 / 31 / 13\end{array}$ \\
\hline 7 & WRNO & 140.4 & 453630122021400 & $\begin{array}{l}\text { Columbia River, left bank, near Dodson, } \\
\text { Oregon (Warrendale) }\end{array}$ & $45^{\circ} 36^{\prime} 30^{\prime \prime}$ & $122^{\circ} 02^{\prime} 14^{\prime \prime}$ & $\begin{array}{l}10 / 01 / 12- \\
09 / 30 / 13\end{array}$ \\
\hline 8 & CWMW & 121.7 & 453439122223900 & $\begin{array}{l}\text { Columbia River, right bank, at Washougal, } \\
\text { Washington (Camas) }\end{array}$ & $45^{\circ} 34^{\prime} 39^{\prime \prime}$ & $122^{\circ} 22^{\prime} 39^{\prime \prime}$ & $\begin{array}{c}03 / 12 / 13- \\
09 / 19 / 13\end{array}$ \\
\hline
\end{tabular}


Instrumentation at each monitoring station consists of a Hach ${ }^{\circledR}$ Hydrolab water-quality instrument, a Vaisala electronic barometer, a Sutron SatLink2 data-collection platform (DCP) and a power supply. The instruments at each station are powered by a 12 -volt battery that is charged by a solar panel or a 120 -volt alternating-current line. Measurements are collected, logged, and transmitted every hour. The DCP transmits the four most recent hours of logged data to the Geostationary Operational Environmental Satellite (GOES) system (Jones and others, 1991). The data are automatically decoded and transferred to the USACE and USGS databases.

Site visits were conducted every 4 weeks at the three year-round stations from September 2012 through March 2013, and every 3 weeks at all eight stations from March 2013 to September 2013. The field calibration procedure was as follows: A reference Hydrolab (which was calibrated before the field trip for use as a secondary standard) was deployed alongside the field-deployed Hydrolab for a period of up to 1 hour to obtain comparison measurements of TDG and water temperature. The field Hydrolab (which had been deployed for 3 or 4 weeks) was then removed and replaced with another Hydrolab that had been calibrated recently in the laboratory. The newly deployed Hydrolab was allowed to equilibrate and the secondary standard was again used to compare TDG and temperature values. The electronic barometer at the monitoring station was calibrated using a portable barometer (NovaLynx 230-M202) that is calibrated annually to NIST standards.

During each field calibration, the minimum compensation depth was calculated to determine whether the Hydrolab was positioned at an appropriate depth to obtain an accurate measurement of TDG. This minimum compensation depth, which was calculated according to Colt (1984, p. 104), is the depth above which degassing will occur due to decreased hydrostatic pressure. To measure TDG accurately, the Hydrolabs were positioned, whenever possible, at a depth below the calculated minimum compensation depth.

The Hydrolab that was removed from the field after 3 or 4 weeks of deployment was then calibrated in the laboratory. The integrity of the TDG membrane was tested, and then the membrane was removed and air-dried. The TDG sensor (without the membrane attached) was calibrated at 0,100, 200, and $300 \mathrm{~mm} \mathrm{Hg}$ (millimeters of mercury) above atmospheric pressure to span the expected range of TDG in the river (approximately 100-, 113-, 126-, and 139-percent saturation, respectively). The membrane was then installed on the TDG sensor and retested.

\section{Data Completeness}

To assure the accuracy and integrity of the TDG data in the lower Columbia River, hourly values were reviewed relative to concurrent field measurements, laboratory instrument calibrations, and daily inter-site comparisons. A summary of the completeness of the TDG percent saturation data is shown in table 2. Data were based on the total number of hourly TDG and barometric pressure data values that could have been collected during the monitoring season. No barometric pressure data were missing when TDG data were available, so data completeness relies on TDG data only. TDG saturation values were considered to meet quality-assurance standards if they were within \pm (plus or minus) 1-percent saturation of the expected value. 
Table 2. Completeness and quality of total-dissolved gas data, lower Columbia River, Oregon and Washington, water year 2013

[TDG, total dissolved gas]

\begin{tabular}{|c|c|c|c|}
\hline $\begin{array}{l}\text { Abbreviated } \\
\text { station name }\end{array}$ & $\begin{array}{l}\text { Planned } \\
\text { monitoring, } \\
\text { in hours }\end{array}$ & $\begin{array}{c}\text { Number of } \\
\text { missing or deleted } \\
\text { hourly values }\end{array}$ & $\begin{array}{l}\text { Percentage of real-time } \\
\text { TDG data passing quali- } \\
\text { ty assurance criteria }\end{array}$ \\
\hline $\begin{array}{l}\text { John Day navigation lock } \\
\text { (JDY) }\end{array}$ & 4,341 & 4 & $99.9 \%$ \\
\hline $\begin{array}{l}\text { John Day tailwater } \\
\text { (JHAW) }\end{array}$ & 8,760 & 81 & $99.1 \%$ \\
\hline $\begin{array}{l}\text { The Dalles forebay } \\
\text { (TDA) }\end{array}$ & 4,342 & 49 & $98.9 \%$ \\
\hline $\begin{array}{l}\text { The Dalles tailwater } \\
\text { (TDDO) }\end{array}$ & 8,760 & 103 & $98.8 \%$ \\
\hline $\begin{array}{l}\text { Bonneville forebay } \\
\text { (BON) }\end{array}$ & 4,344 & 1 & $100 \%$ \\
\hline $\begin{array}{l}\text { Cascade Island } \\
\text { (CCIW) }\end{array}$ & 4,081 & 94 & $97.7 \%$ \\
\hline $\begin{array}{l}\text { Warrendale } \\
\text { (WRNO) }\end{array}$ & 8,760 & 17 & $99.8 \%$ \\
\hline $\begin{array}{l}\text { Camas } \\
\text { (CWMW) }\end{array}$ & 4,580 & 23 & $99.5 \%$ \\
\hline TOTAL & 47,968 & 372 & $99.2 \%$ \\
\hline
\end{tabular}

Periods for which substantial periods of TDG data were either missing from the database or for which data were later deleted from the database because they did not meet qualityassurance standards are listed in table 3. Inclem- ent weather (most likely ice build-up on the transmission antennas), power supply problems, damaged deployment structures and ruptured TDG membranes were the most common causes of missing or deleted data. 
Table 3. Periods of missing real-time TDG data, lower Columbia River, Oregon and Washington, water year 2013

[USACE station identifier: JDY, John Day navigation lock; JHAW, John Day tailwater; TDA The Dalles forebay; TDDO, The Dalles tailwater; BON, Bonneville forebay; CCIW, Cascade Island; WRNO, Warrendale; CWMW, Camas.]

\begin{tabular}{|c|c|c|}
\hline Date & $\begin{array}{l}\text { USACE station } \\
\text { identifier }\end{array}$ & Reason / Note \\
\hline $\begin{array}{l}11 / 23 / 12 \text { to } 11 / 29 / 12 \\
12 / 07 / 12 \text { to } 12 / 22 / 12\end{array}$ & JHAW & Failed satellite transmissions due to inclement weather \\
\hline $09 / 25 / 13$ to $09 / 26 / 13$ & JHAW & $\begin{array}{l}\text { Primary sensor had a ruptured membrane, secondary sensor } \\
\text { values were too high according to field check }\end{array}$ \\
\hline $05 / 18 / 13$ to $05 / 20 / 13$ & TDA & Failed satellite transmissions due to low battery \\
\hline $01 / 20 / 13$ to $01 / 21 / 13$ & TDDO & Failed satellite transmissions due to inclement weather \\
\hline $02 / 02 / 13$ to $02 / 12 / 13$ & TDDO & $\begin{array}{l}\text { Intermittent failed data collection and satellite transmis- } \\
\text { sions due to low battery }\end{array}$ \\
\hline $05 / 16 / 13$ to $05 / 17 / 13$ & CCIW & $\begin{array}{l}\text { TDG values were too low compared to data at adjacent } \\
\text { sites }\end{array}$ \\
\hline $08 / 29 / 13$ to $08 / 31 / 13$ & CCIW & $\begin{array}{l}\text { Communication with TDG sensor failed due to damage to } \\
\text { installation pipe }\end{array}$ \\
\hline $01 / 04 / 13$ & WRNO & Failed satellite transmissions due to inclement weather \\
\hline $09 / 05 / 13$ to $09 / 06 / 13$ & CWMW & Ruptured membrane on TDG sensor \\
\hline
\end{tabular}

\section{Quality-Assurance Data}

The collection of accurate data for TDG, barometric pressure, and water temperature involves several quality-assurance procedures, including side-by-side instrument comparisons in the field, sensor calibrations in the laboratory, daily checks of the data, and data review and archiving. The results of the quality-assurance procedures for water year 2013 are presented in this section.

After field deployment for 3 or 4 weeks, the TDG instruments were calibrated in the laboratory. First, the sensor was tested, with the gas permeable membrane in place, for response to supersaturated conditions. The membrane was then removed from the sensor and allowed to dry for at least 24 hours. Before replacing the mem- brane, the TDG sensor was examined independently by comparing the reading of the TDG sensor to barometric pressure (100-percent saturation). Using a certified digital pressure gage (primary standard), comparisons also were made at pressures of 100, 200, and $300 \mathrm{~mm} \mathrm{Hg}$ above barometric pressure (approximately 113-, 126-, and 139-percent saturation, respectively). The accuracy of the TDG sensors was calculated as the difference between the primary standard and the TDG sensor reading (expected minus actual) for each of the four test conditions divided by the barometric pressure and multiplied by 100 to obtain a percentage difference. Of the 98 laboratory checks that were performed on instruments after field deployment, all were within 0.5 -percent saturation (fig. 2). 


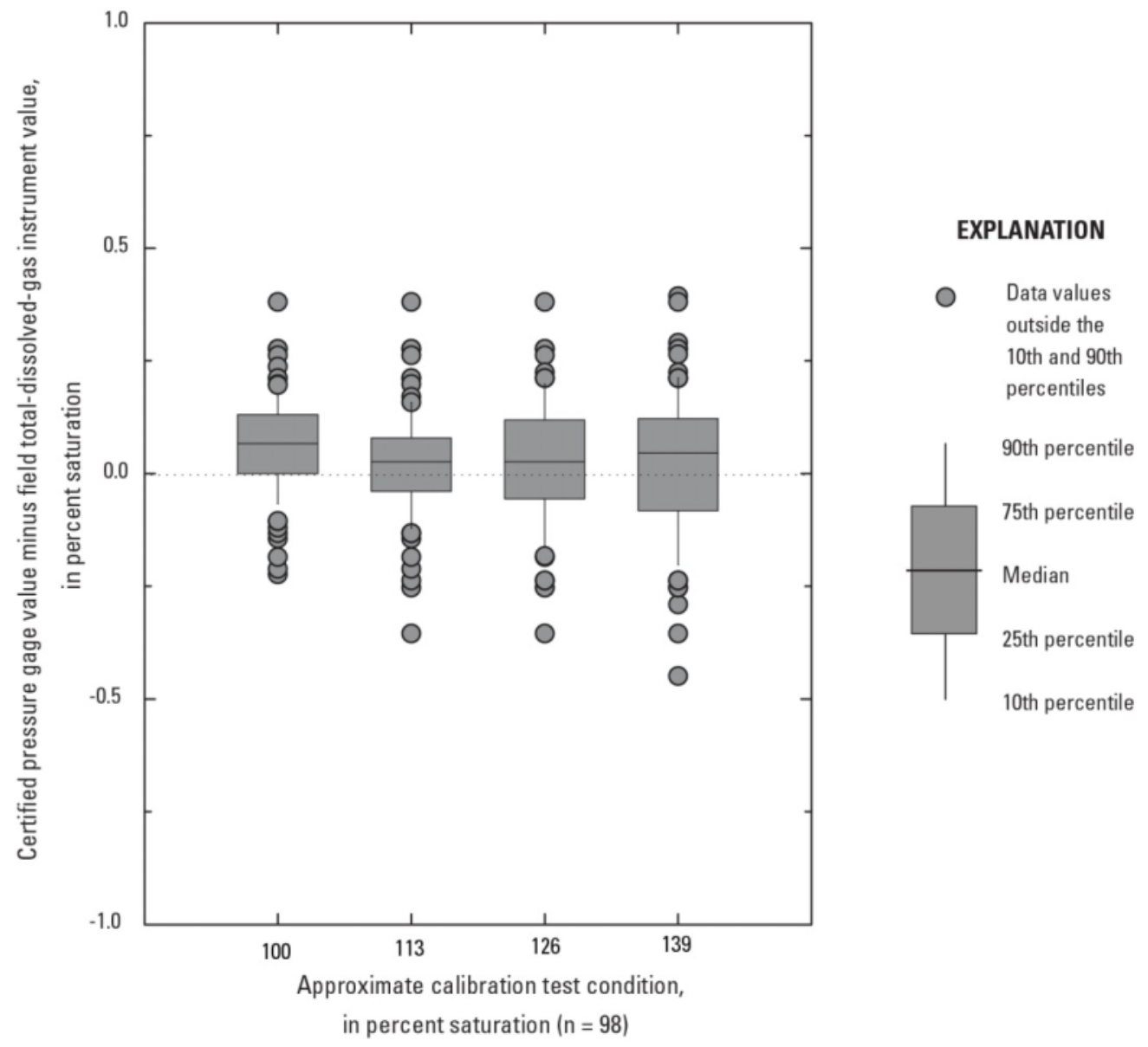

Figure 2. Boxplot showing accuracy of total-dissolved-gas sensors in the laboratory after 3 or 4 weeks of field deployment at eight monitoring stations in the lower Columbia River, Oregon and Washington, water year 2013 (number of comparison values $=98$ ).

The differences in barometric pressure, water temperature, and TDG between the secondary standard instruments and the station monitors at the end of their field deployment were measured and recorded as part of every field inspection and calibration procedure. These differences, calculated as the secondary standard values minus the field instrument values, were used to compare and quantify the accuracy and precision between the two instruments. For water temperature and TDG, the measurements were made with the secondary standard (a recently calibrated Hydrolab) positioned alongside the Hydrolab deployed in the river. A digital barometer, NIST certified through May 2014, served as the primary standard for barometric pressure. Figures 3, 4, and 5 illustrate the distribution of quality-assurance data for each of the three parameters from the eight stations.

The comparisons of the digital barometer and the field barometers are shown in figure 3 . All but one of the field values were within $1 \mathrm{~mm}$ $\mathrm{Hg}$ of standard values. The secondary standard temperature sensor and the field temperature sensor results are presented in figure 4. All differences were within $0.2^{\circ} \mathrm{C}$. 


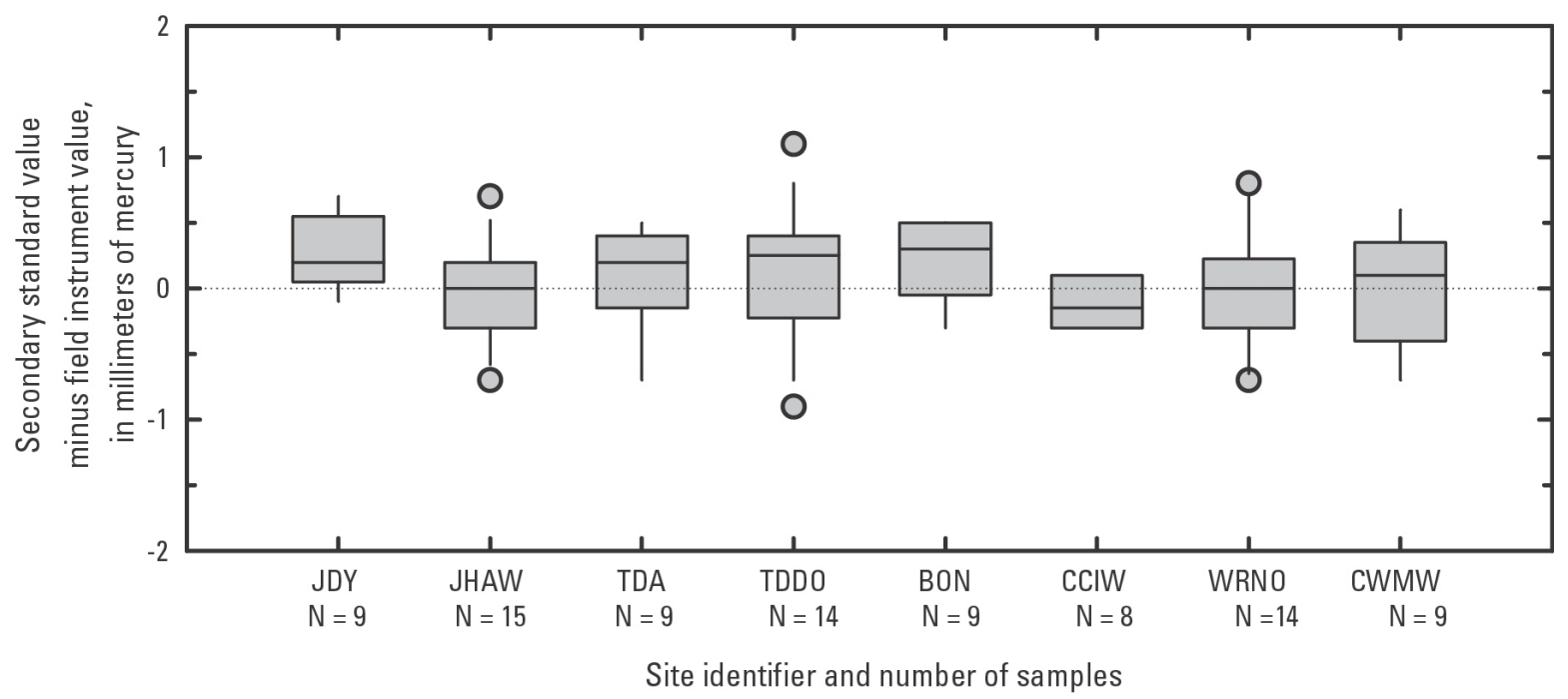

Figure 3. Boxplot showing difference between the secondary standard and the field barometers in the field after 3 or 4 weeks of field deployment at eight stations in the lower Columbia River, Oregon and Washington, water year 2013. See figure 2 for explanation of boxplots.

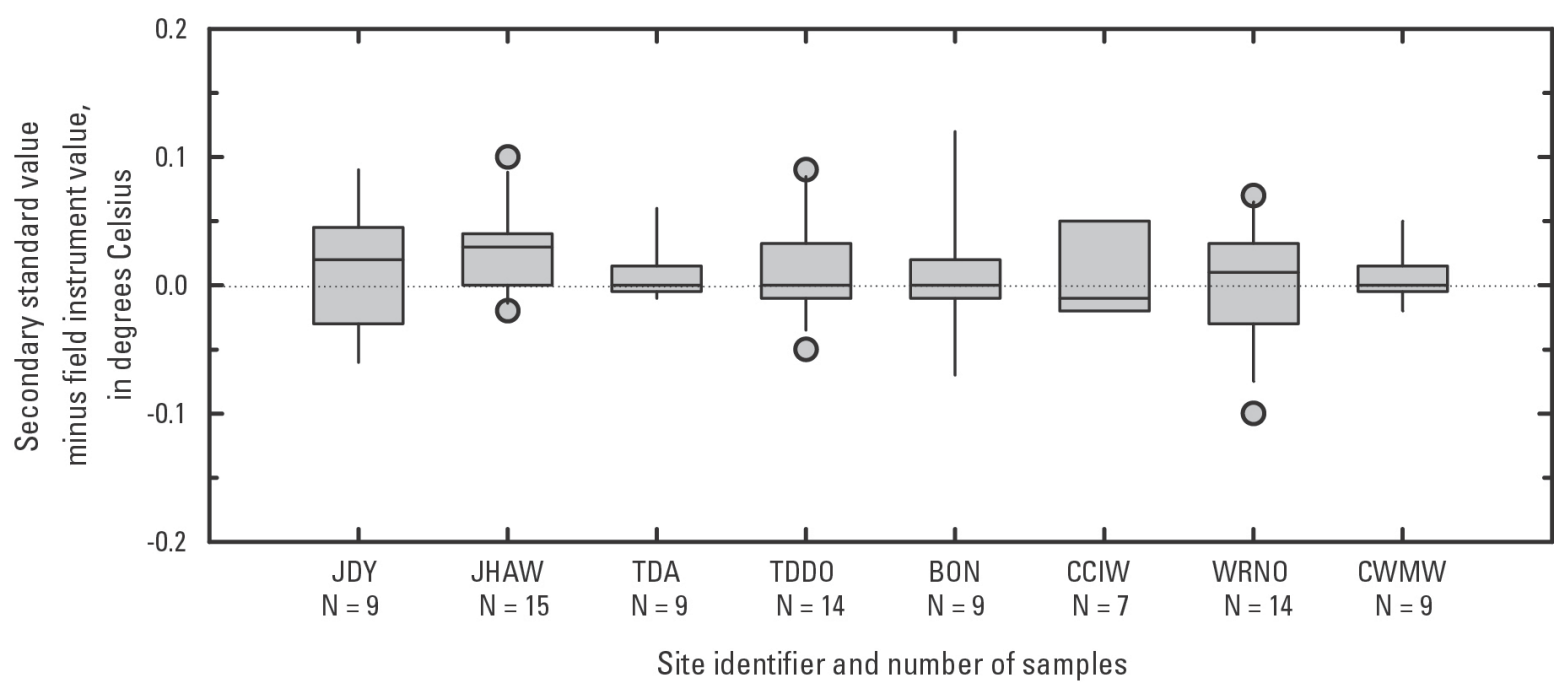

Figure 4. Boxplot showing difference between the secondary standard and the field temperature instruments in the field after 3 or 4 weeks of field deployment at eight stations in the lower Columbia River, Oregon and Washington, water year 2013. See figure 2 for explanation of boxplots.

Differences between the secondary standard TDG sensor and the field TDG sensors were calculated following equilibration of the secondary standard instrument to the site conditions before removing the field instrument. The side-by-side equilibrium was considered complete after a minimum of 20 minutes when the TDG values for each sensor remained constant for 3-5 minutes. With the exception of two ruptured membranes (for which no comparison readings could be taken), only one of the TDG field checks indicated a saturation difference greater than 1.0 percent (fig. 5). The auxiliary sensor at John Day tailwater began logging erroneously high TDG data the day prior to the field check. The cause could not be determined, and the instrument was replaced during the field visit. 


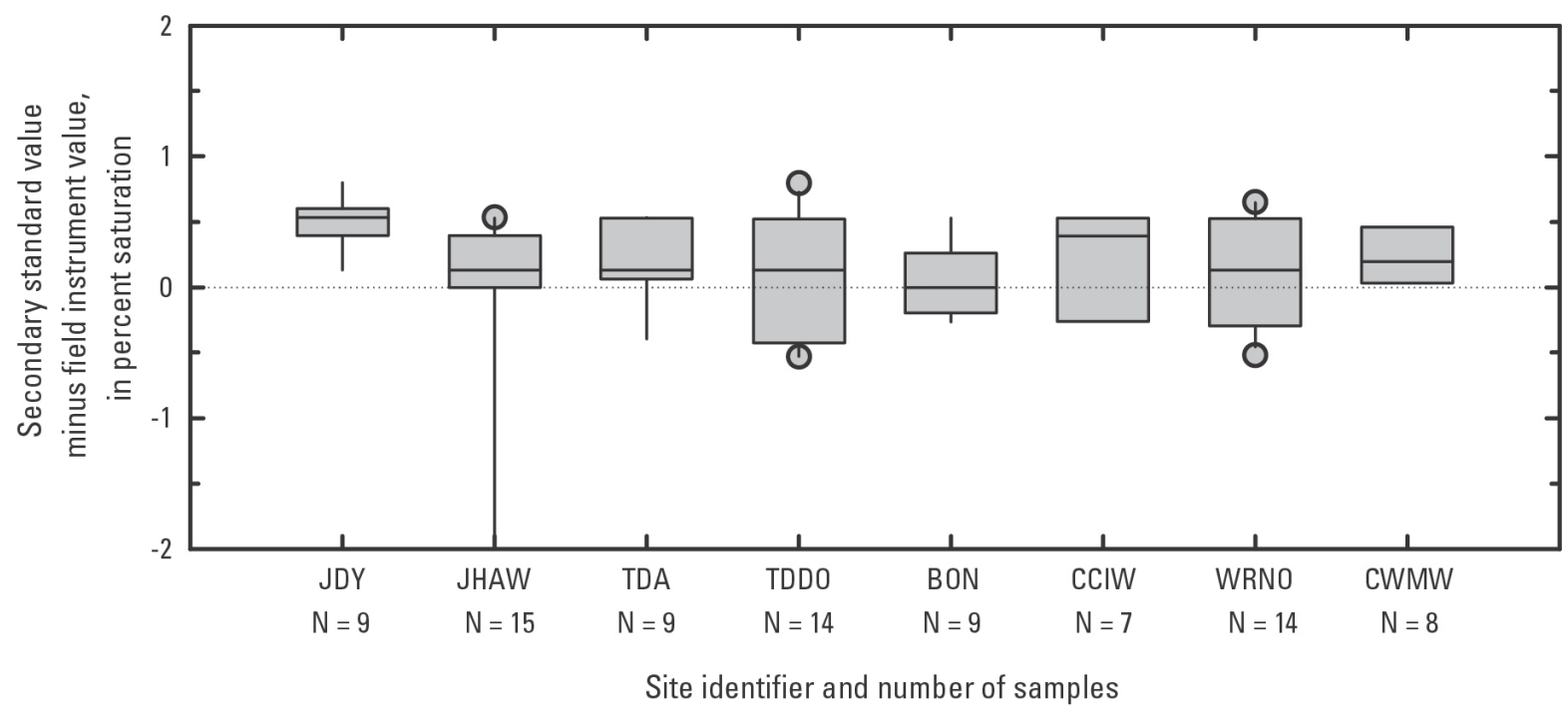

Figure 5. Boxplot showing difference between the secondary standard and the field total-dissolved-gas instruments in the field after 3 or 4 weeks of field deployment at eight stations in the lower Columbia River, Oregon and Washington, water year 2013. See figure 2 for explanation of boxplots.

\section{Effects of Spill on Total-Dissolved- Gas Saturation}

The relation between spill discharge at the dams and TDG at the corresponding tailwater site or sites are shown for John Day Dam (fig. 6), The Dalles Dam (fig. 7), and Bonneville Dam (figs. 8 and 9). For spill between approximately 25,000 and $70,000 \mathrm{ft}^{3} / \mathrm{s}$, the TDG saturation be- low John Day Dam remained relatively level between 111 percent and 116 percent. For spill greater than $70,000 \mathrm{ft}^{3} / \mathrm{s}$, the TDG saturation increased steadily with greater spill. At the stations below The Dalles Dam and Bonneville Dam, the TDG saturation values generally increased with greater spill over the entire range of values. 


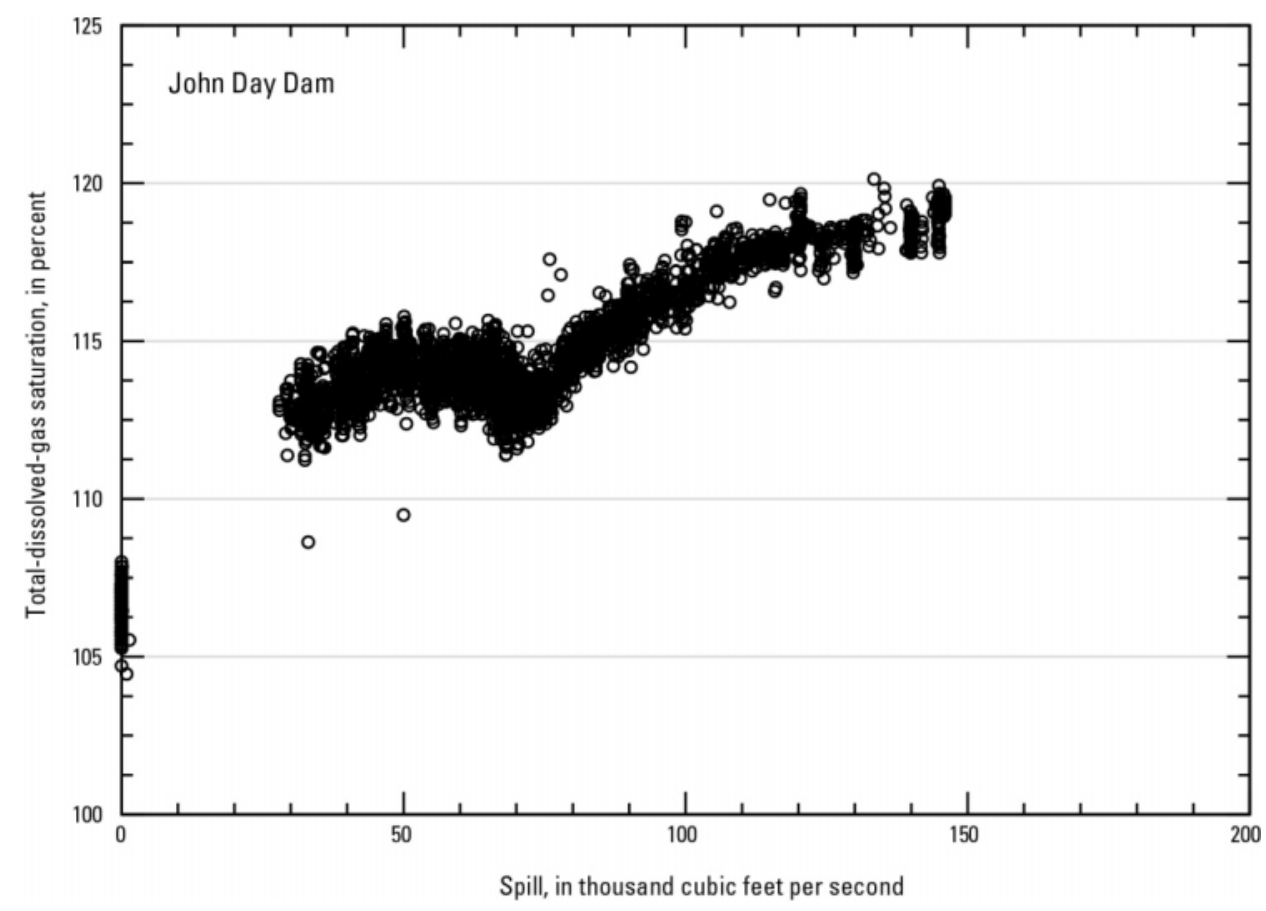

Figure 6. Graph showing relation of total-dissolved-gas saturation downstream of John Day Dam and spill from the dam, lower Columbia River, Oregon and Washington, April 1-August 31, 2013.

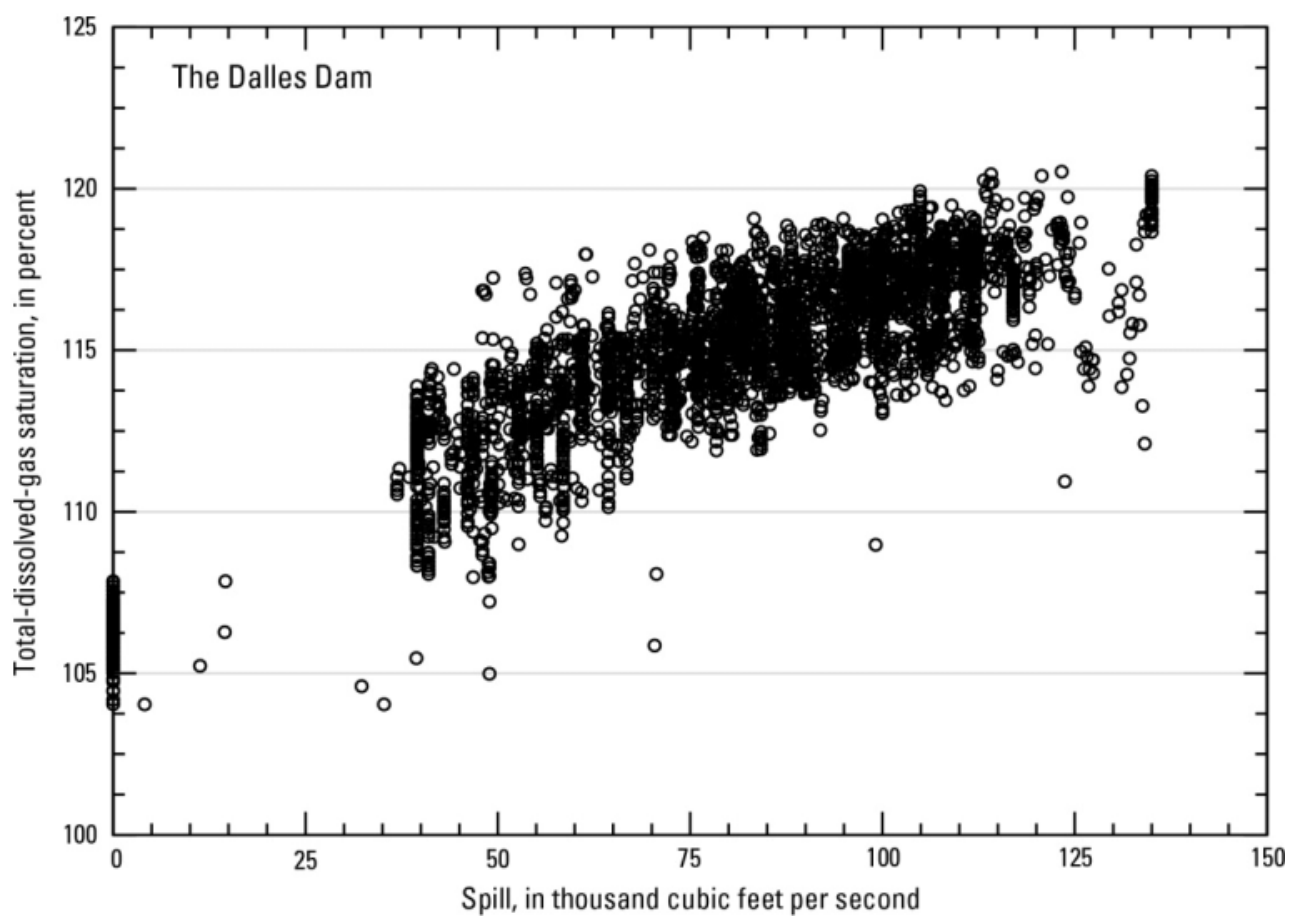

Figure 7. Graph showing relation of total-dissolved-gas saturation downstream of The Dalles Dam and spill from The Dalles Dam, lower Columbia River, Oregon and Washington, April 1-August 31, 2013. 


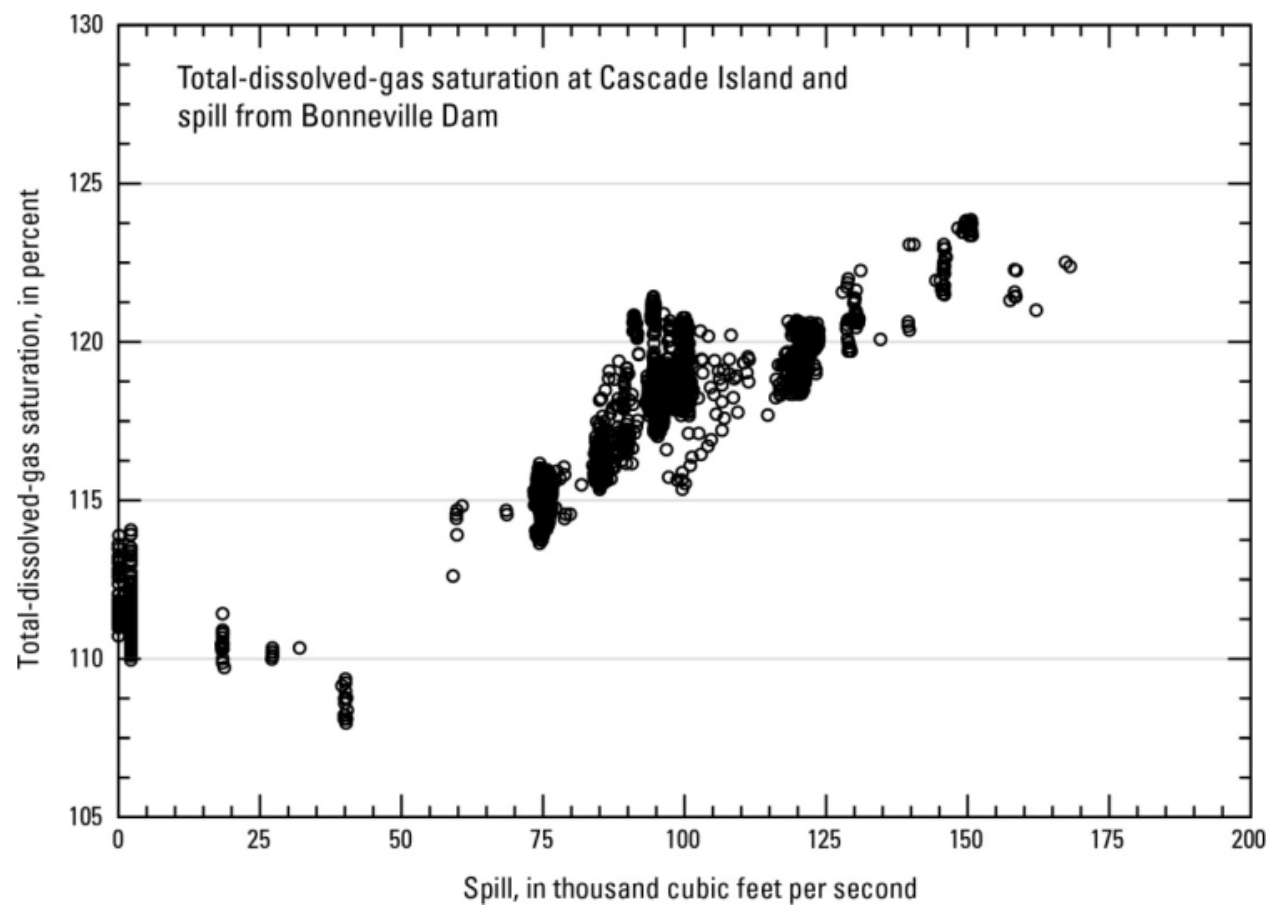

Figure 8. Graph showing relation of total-dissolved-gas saturation downstream of Bonneville Dam at Cascade Island and spill from Bonneville Dam, lower Columbia River, Oregon and Washington, April 1-August 31, 2013

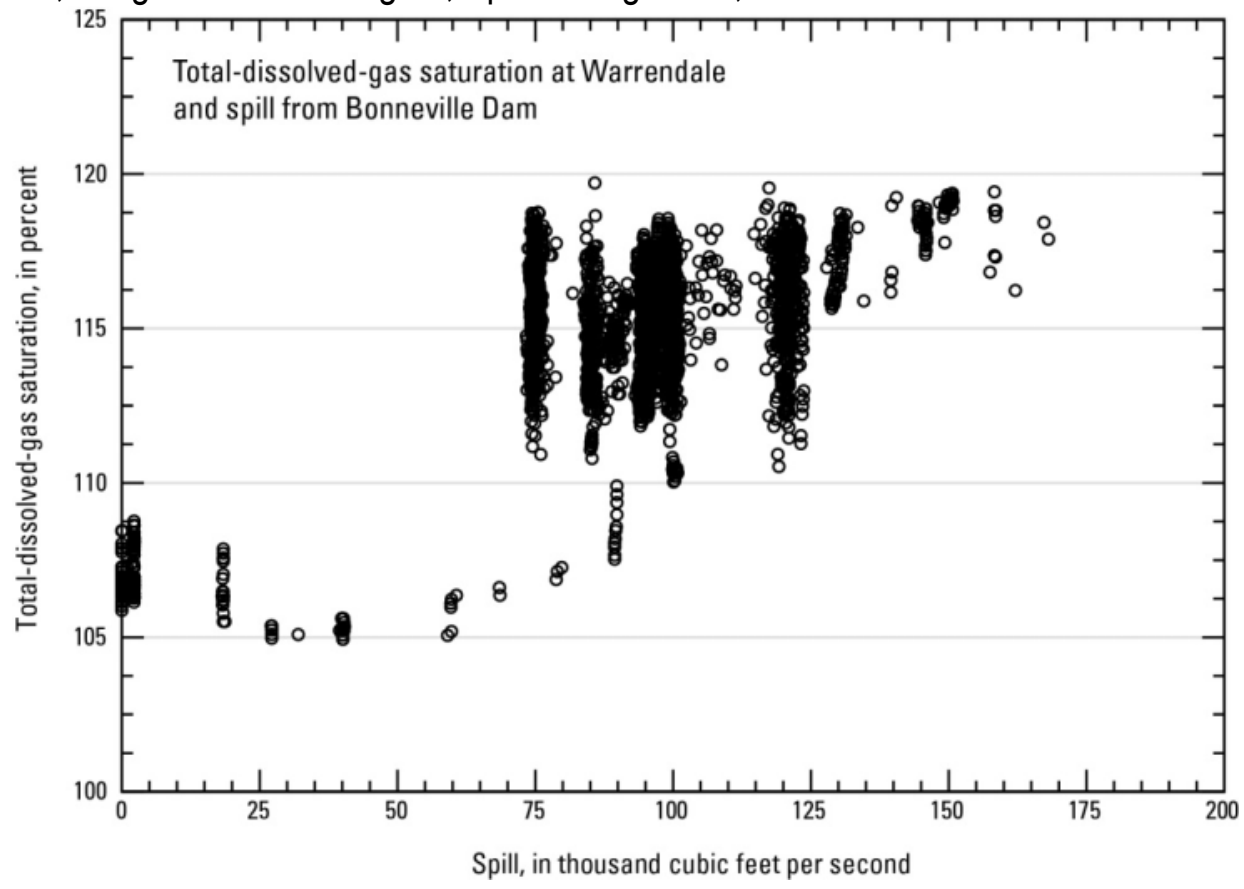

Figure 9. Graph showing relation of total-dissolved-gas saturation downstream of Bonneville Dam at Warrendale and spill from Bonneville Dam, lower Columbia River, Oregon and Washington, April 1-August 31, 2013 


\section{Summary of Total-Dissolved-Gas and Water-Temperature Data}

The States of Oregon and Washington have granted waivers (Oregon) or criteria adjustments (Washington) to the water-quality standard of 110-percent for TDG saturation. These exceptions have been issued to allow for the passage of fish through the dams on the Columbia River. Both States allow daily TDG values to reach 115-percent saturation at the forebay stations (John Day Dam navigation lock, The Dalles Dam forebay, and Bonneville Dam forebay) and Camas, and 120-percent saturation at tailwater stations (John Day Dam tailwater, The Dalles Dam tailwater, Cascade Island, and Warrendale). However, the computation of the daily TDG val- ue differs for each State. For water year 2013, the USACE calculated daily TDG using the Oregon method, which averages the highest 12 hourly readings of each day (1:00 a.m. to midnight) (State of Oregon, 2009).

The distribution of hourly TDG values for the 2013 spill season (April 1 through August 31, 2013 ) is shown in figure 10 . The applicable TDG water-quality reference value for each station (115 percent or 120 percent) is shown with the data. The plots show the hourly TDG values, whereas the water-quality standards apply to a daily average value. Consequently, each of the points greater than the reference values on the graph does not necessarily represent an exceedance of any water-quality standards.

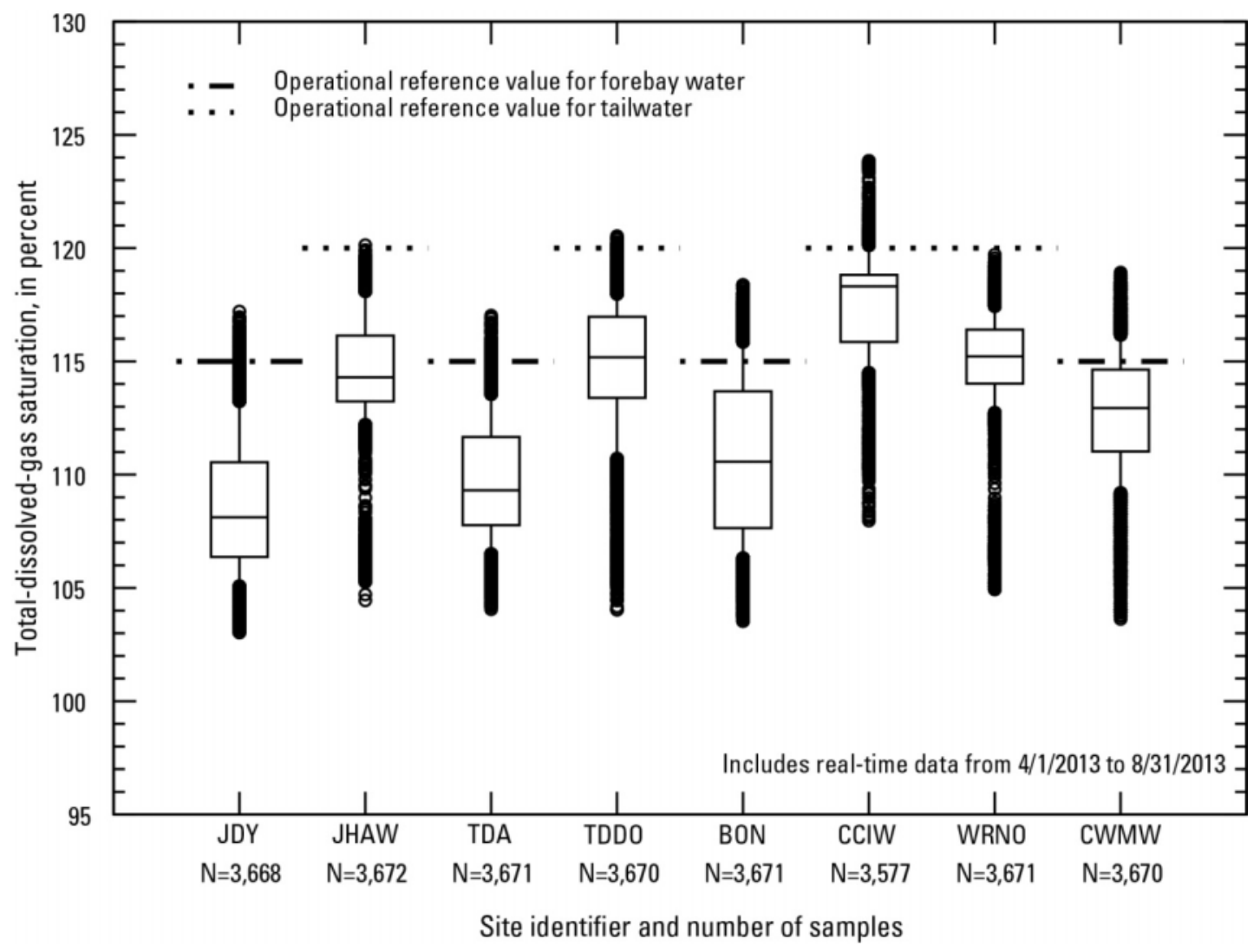

Figure 10. Boxplot showing distributions of hourly total-dissolved-gas data, lower Columbia River, Oregon and Washington, April 1-August 31, 2013. See figure 2 for explanation of boxplots. 
Time-series plots of the TDG percent saturation and the spill at the closest upstream dam are shown in figures 11 through 18 . For the calculations of the high 12-hour average, missing TDG data were ignored and the next adjacent data points were used for the computation. The two upstream forebay sites (John Day Dam navigation lock and The Dalles Dam forebay) each had short durations exceeding 115-percent TDG saturation in May, June and July. In addition to those months, Bonneville Dam forebay also had average daily values greater than 115 percent in April. Camas exceeded 115-percent saturation at times during all 5 months of the spill season. Three of the tailwater sites (John Day Dam tailwater, The Dalles Dam tailwater, and Warrendale) did not exceed 120-percent saturation at any time during the spill season. For a few days in April and many days in May, Cascade Island had average daily values greater than 120 percent. 

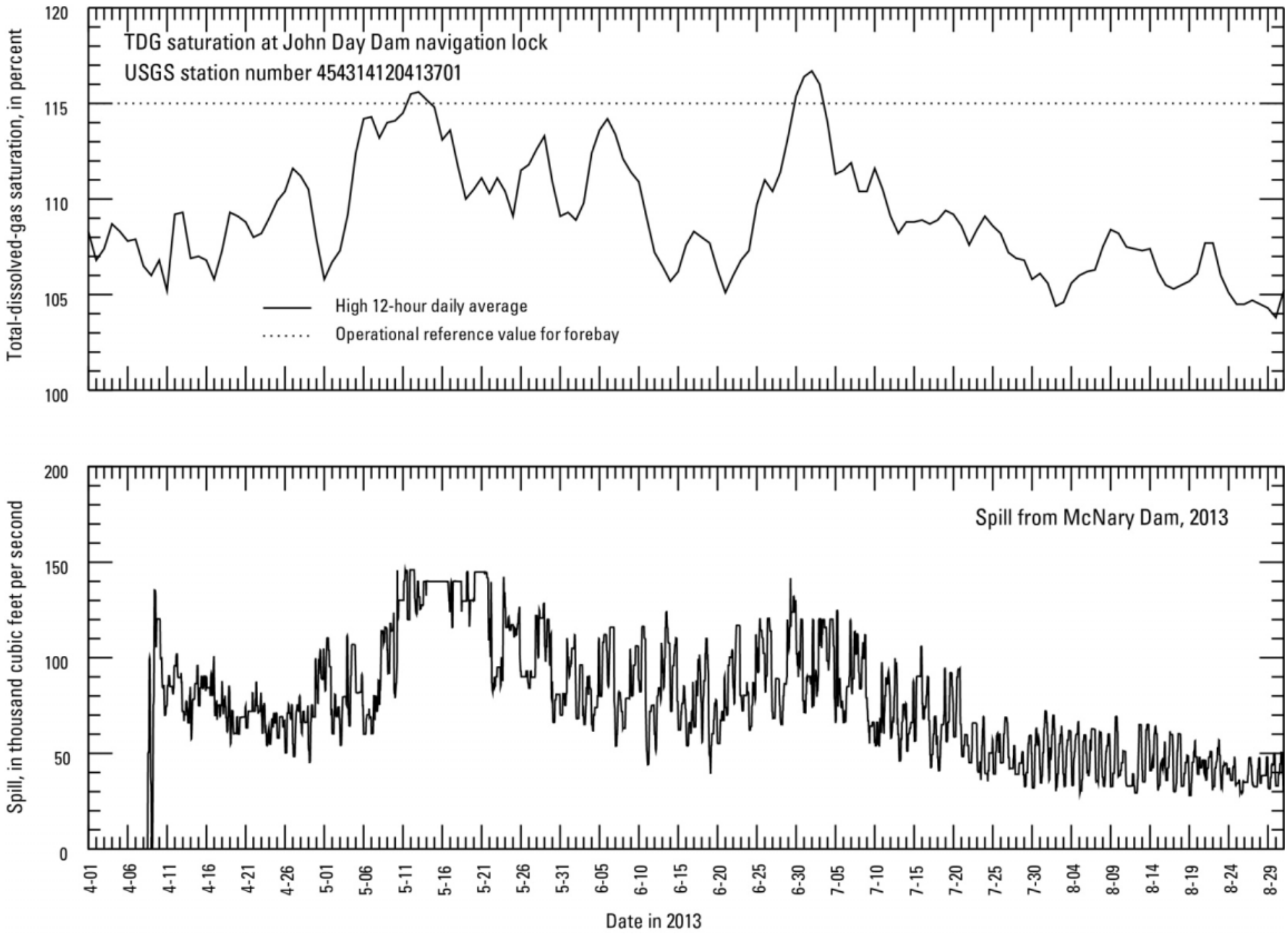

Figure 11. Graphs showing high 12-hour average of total-dissolved-gas saturation at John Day Dam navigation lock and spill from McNary Dam (76 river miles upstream from John Day Dam), lower Columbia River, Oregon and Washington, April 1-August 31, 2013. 


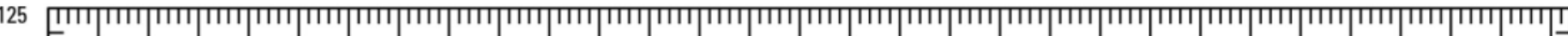
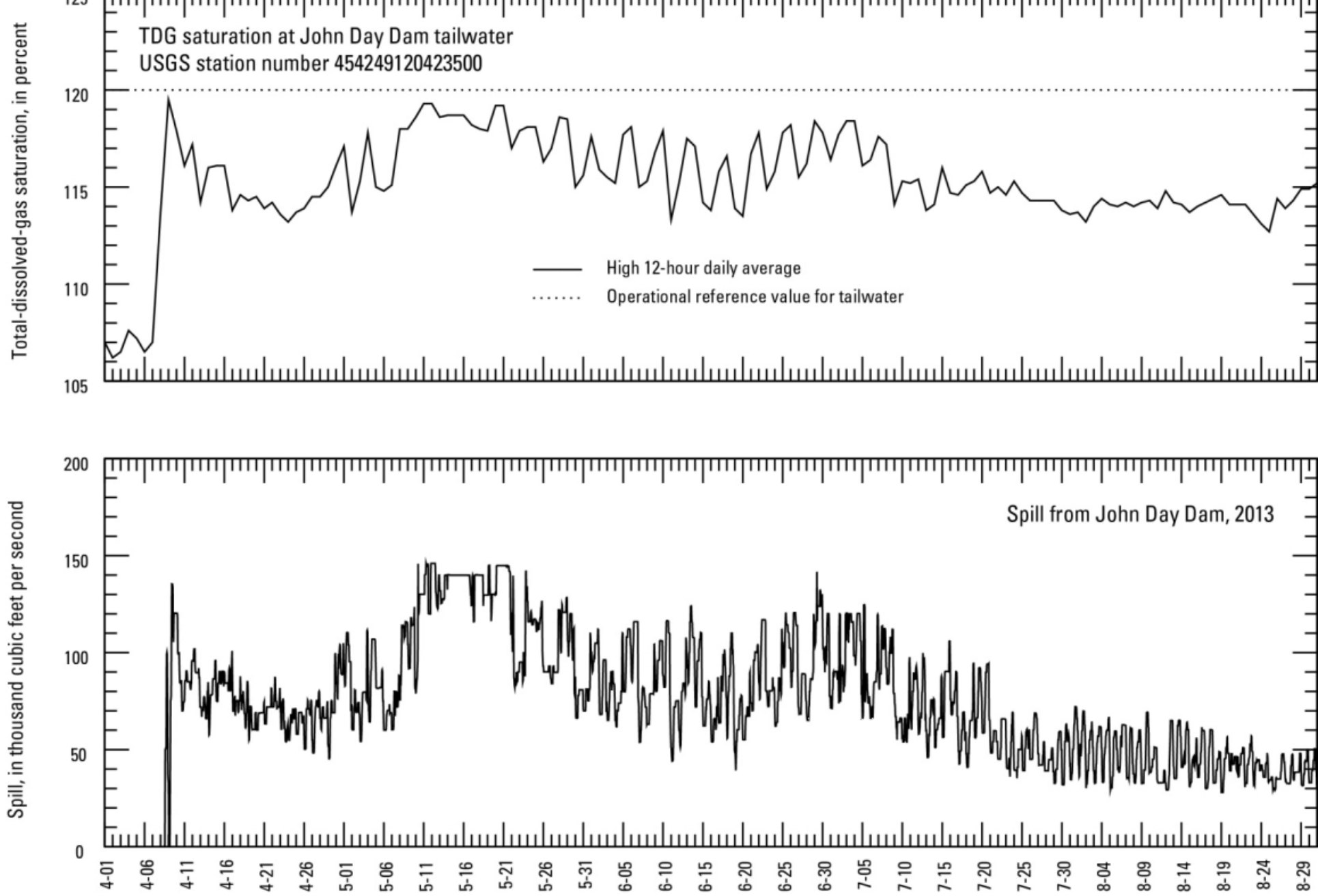

Date in 2013

Figure 12. Graphs showing total-dissolved-gas saturation at John Day Dam tailwater and spill from John Day Dam, lower Columbia River, Oregon and Washington, April 1-August 31, 2013. 

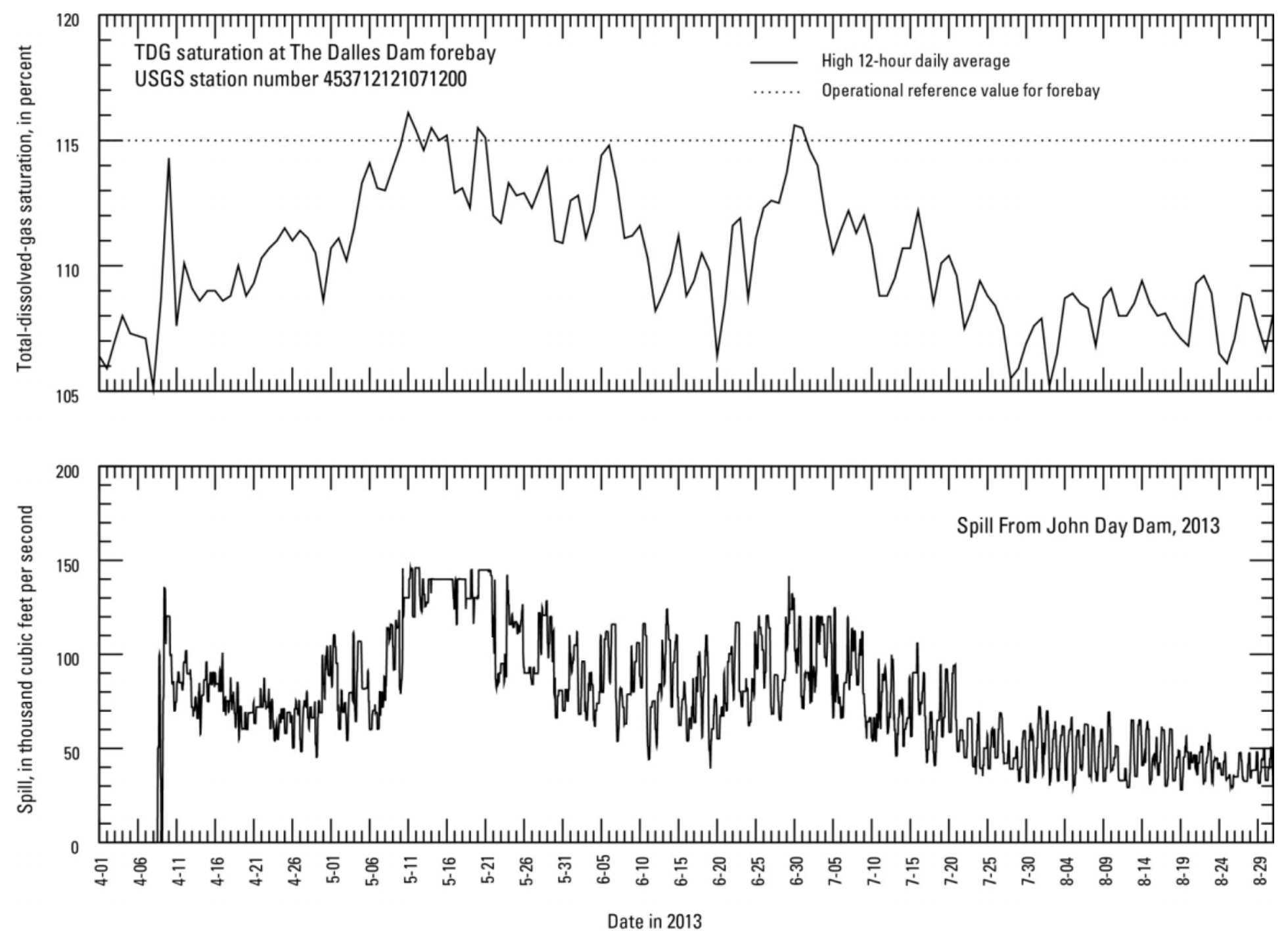

Figure 13. Graphs showing total-dissolved-gas saturation at The Dalles Dam forebay and spill from John Day Dam, lower Columbia River, Oregon and Washington, April 1-August 31, 2013. 

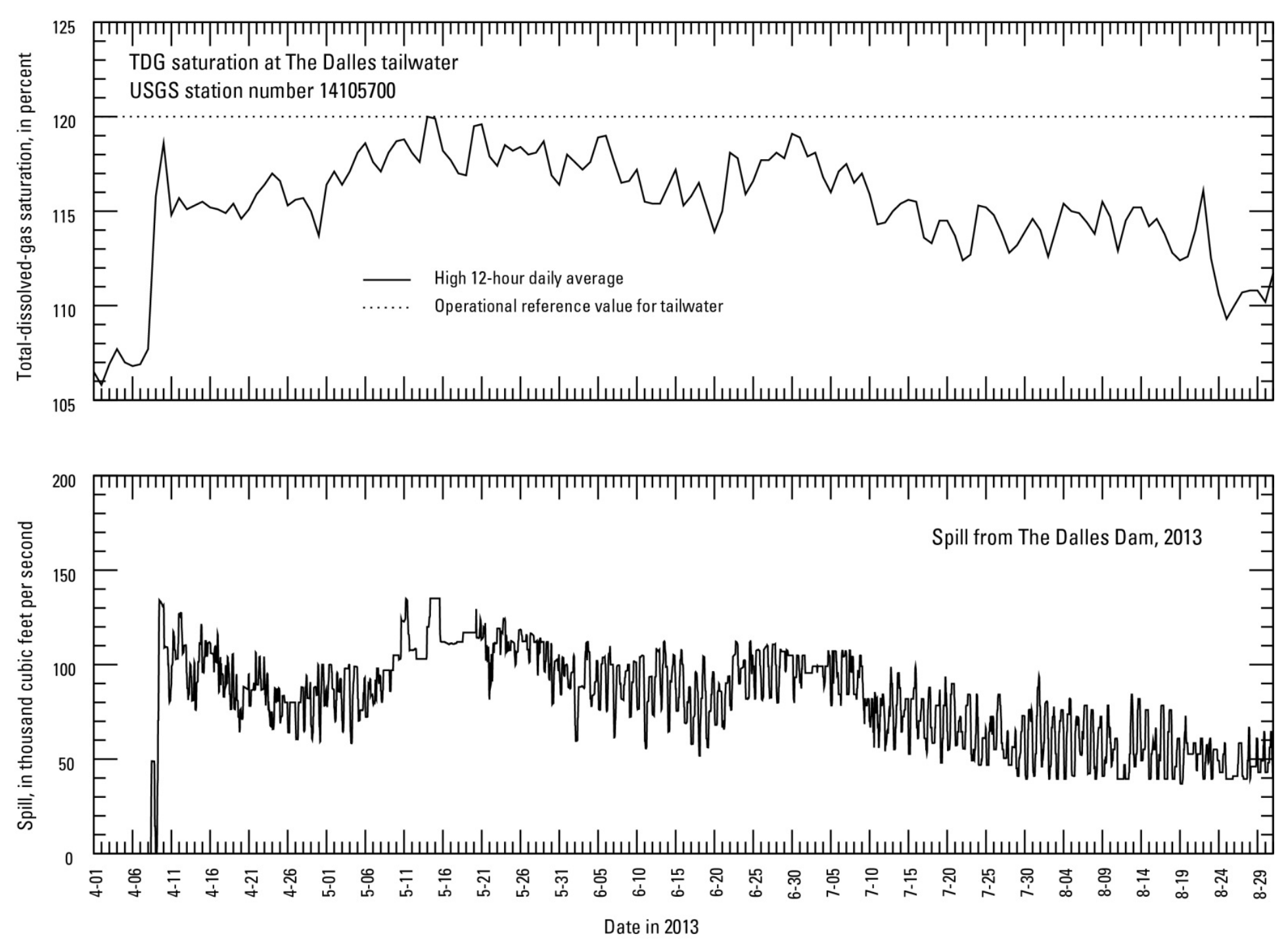

Figure 14. Graphs showing total-dissolved-gas saturation at The Dalles Dam tailwater and spill from The Dalles Dam, lower Columbia River, Oregon and Washington, April 1-August 31, 2013. 

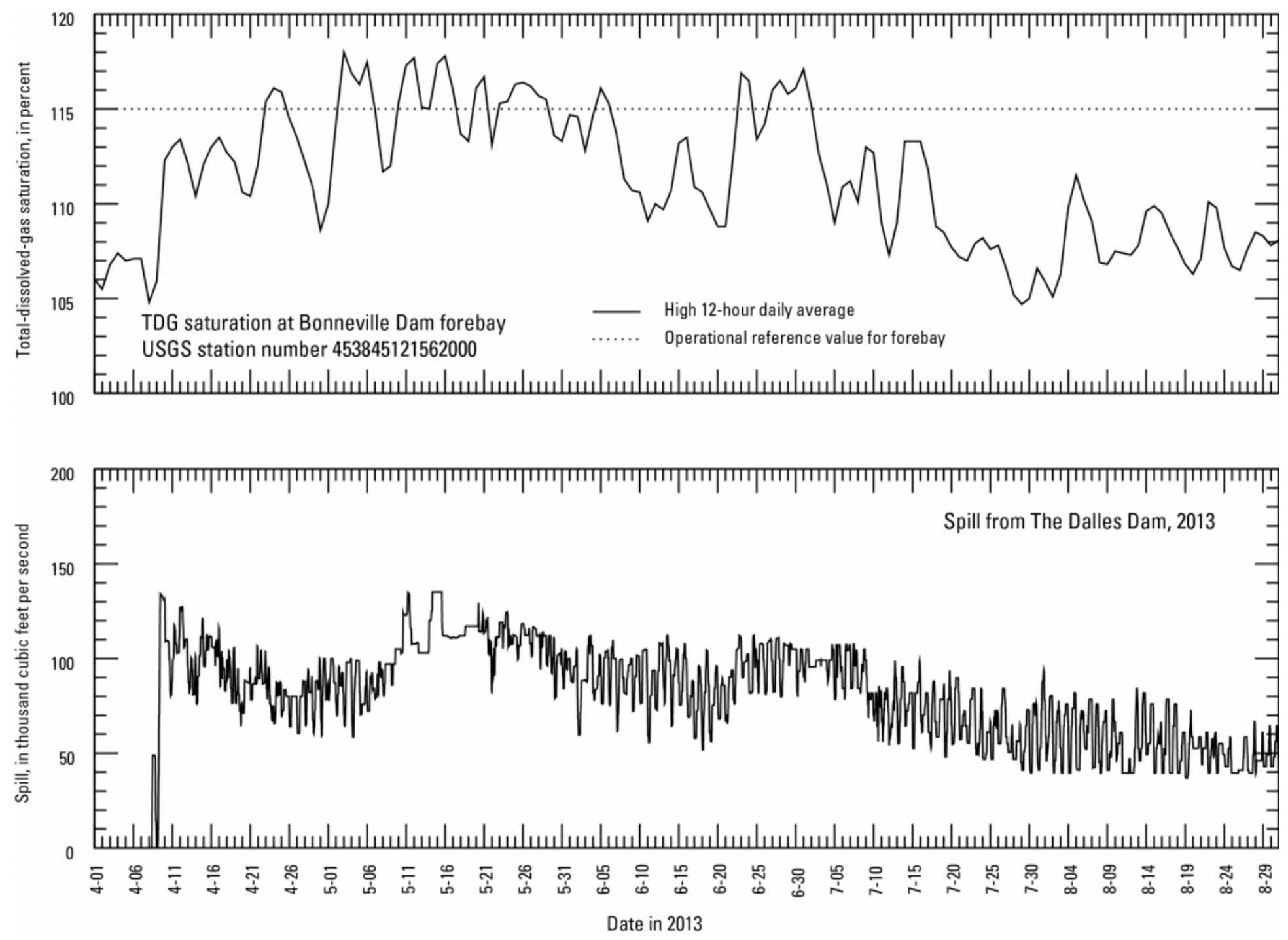

Figure 15. Graphs showing total-dissolved-gas saturation at Bonneville Dam forebay and spill from The Dalles Dam, lower Columbia River, Oregon and Washington, April 1-August 31, 2013. 

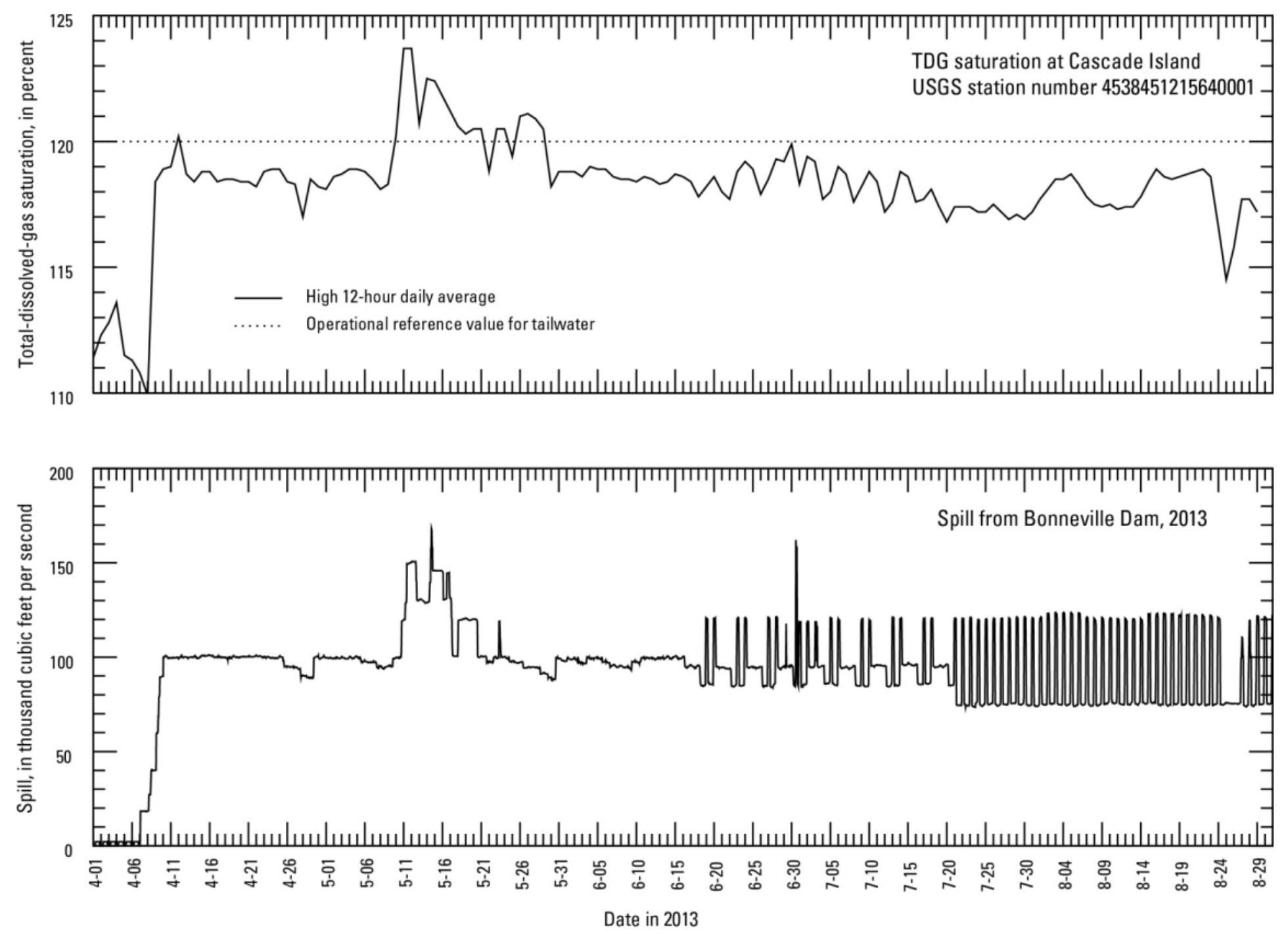

Figure 16. Graphs showing total-dissolved-gas saturation at Cascade Island and spill from Bonneville Dam, lower Columbia River, Oregon and Washington, April 1-August 31, 2013. 


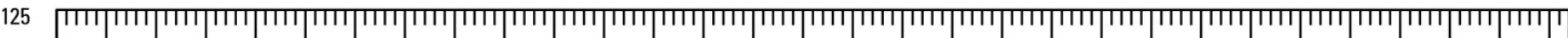
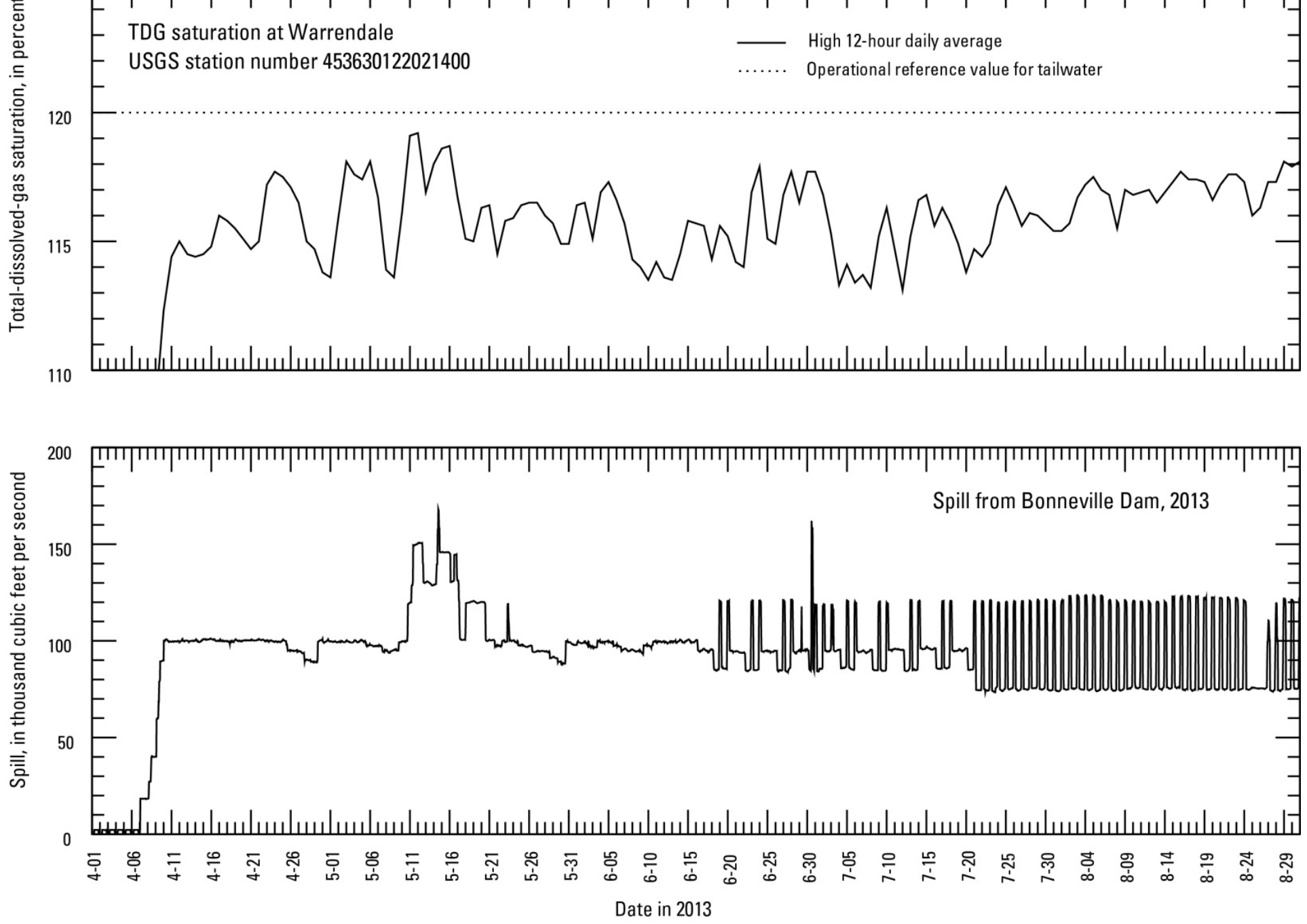

Figure 17. Graphs showing total-dissolved-gas saturation at Warrendale and spill from Bonneville Dam, lower Columbia River, Oregon and Washington, April 1-August 31, 2013. 

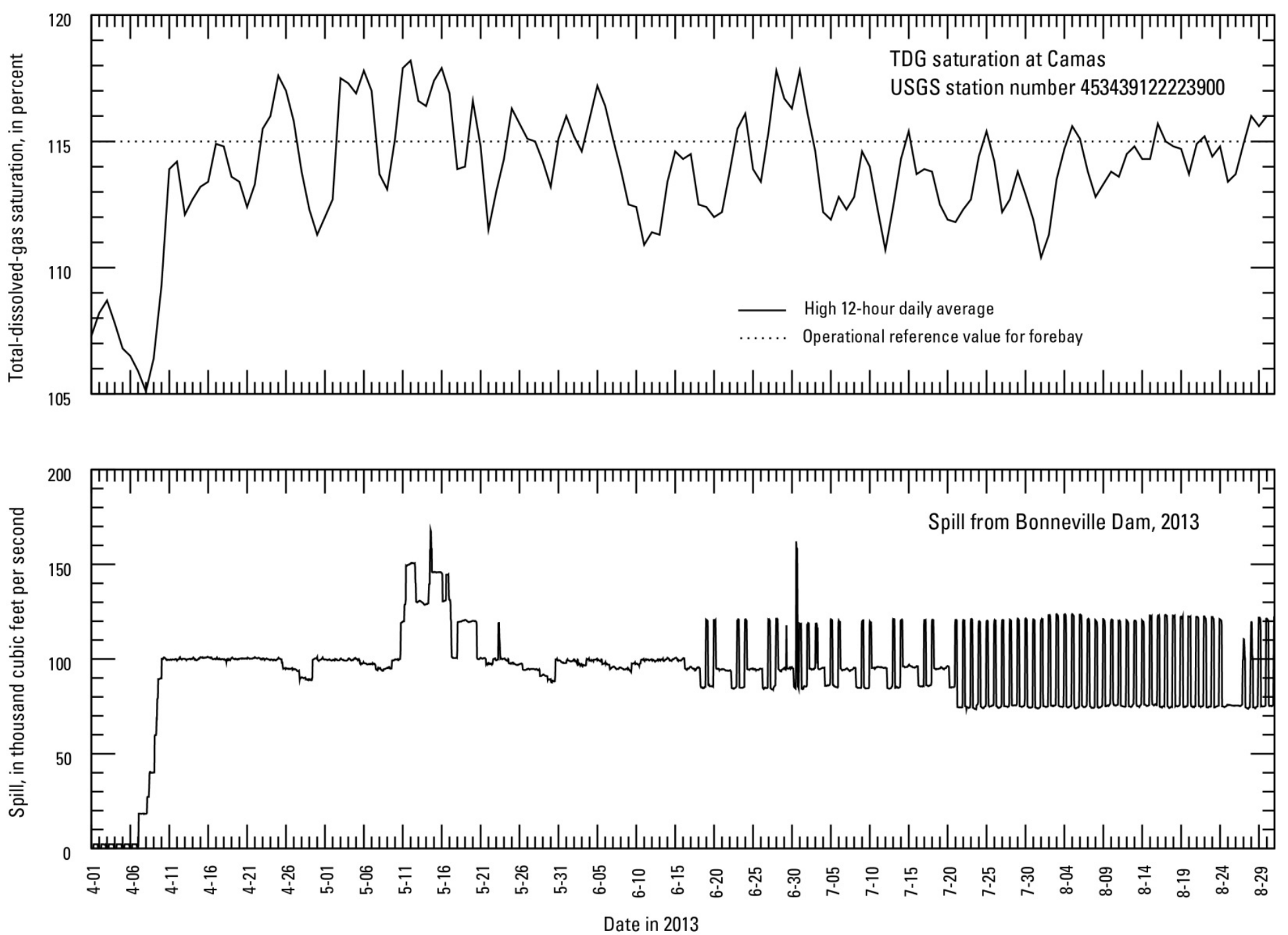

Figure 18. Graphs showing total-dissolved-gas saturation at Camas and spill from Bonneville Dam, lower Columbia River, Oregon and Washington, April 1-August 31, 2013. 
Water-temperature standards that apply to the lower Columbia River are complex and depend on the effects of human activities and the locations of salmonid rearing, spawning, and egg incubation areas. According to the State of Oregon water-temperature standard, the 7-dayaverage of the daily maximum temperature of the lower Columbia River should not exceed $20^{\circ} \mathrm{C}$ (State of Oregon, 2008). Washington State regulations mandate that the water temperature in the Columbia River shall not exceed a 1-day maxi- mum of $20.0^{\circ} \mathrm{C}$ due to human activities (State of Washington, 2006).

Figures 19-23 show only the hourly values for water temperature. Water temperatures at all sites were greater than $20.0^{\circ} \mathrm{C}$ during parts of July, August, and September. Water temperatures at the forebay stations were approximately equal to the temperatures at the tailwater stations, except during short time periods at the John Day Dam sites.

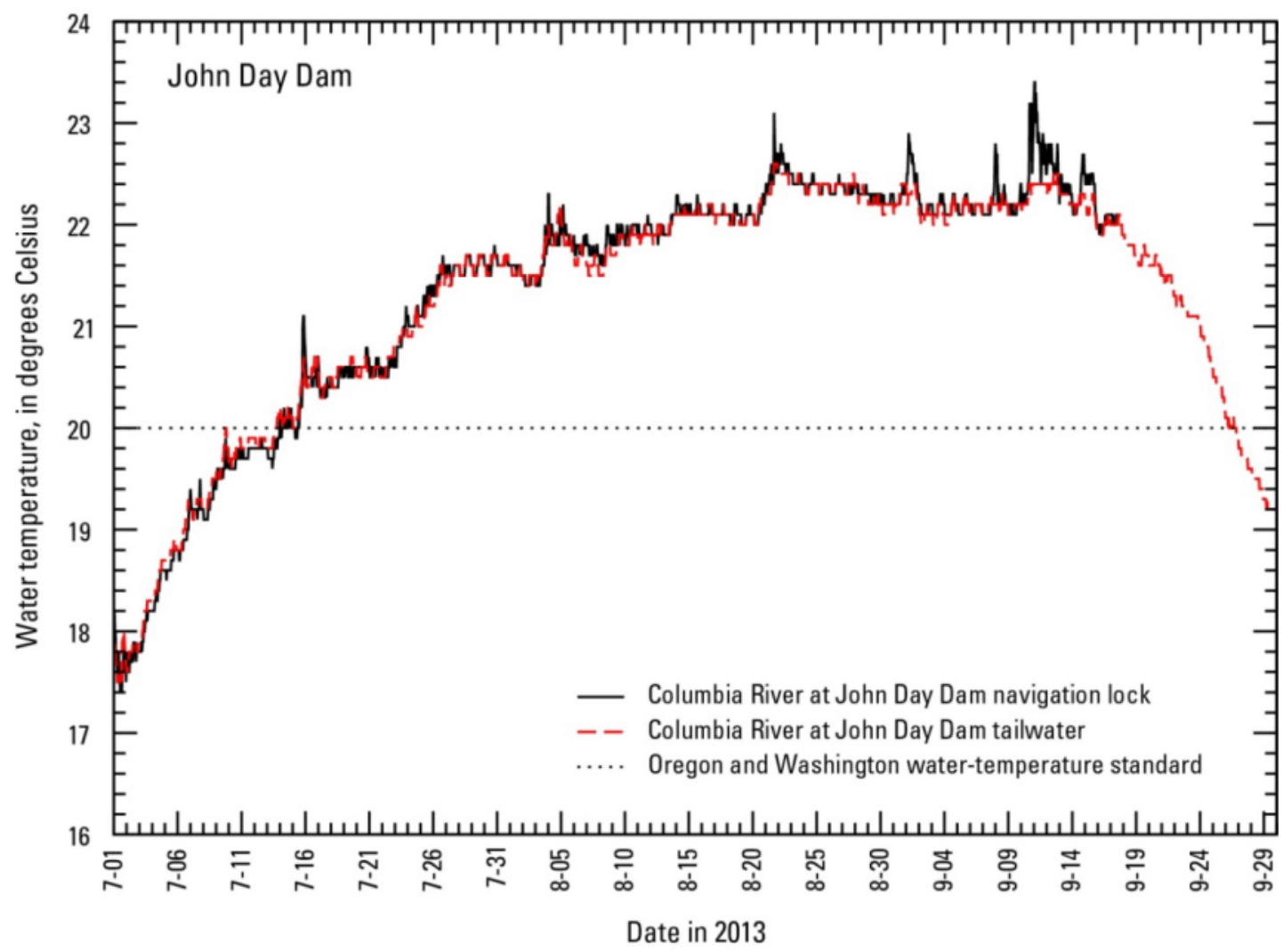

Figure 19. Graph showing water temperature upstream of John Day Dam and downstream of John Day Dam, lower Columbia River, Oregon and Washington, summer 2013. 


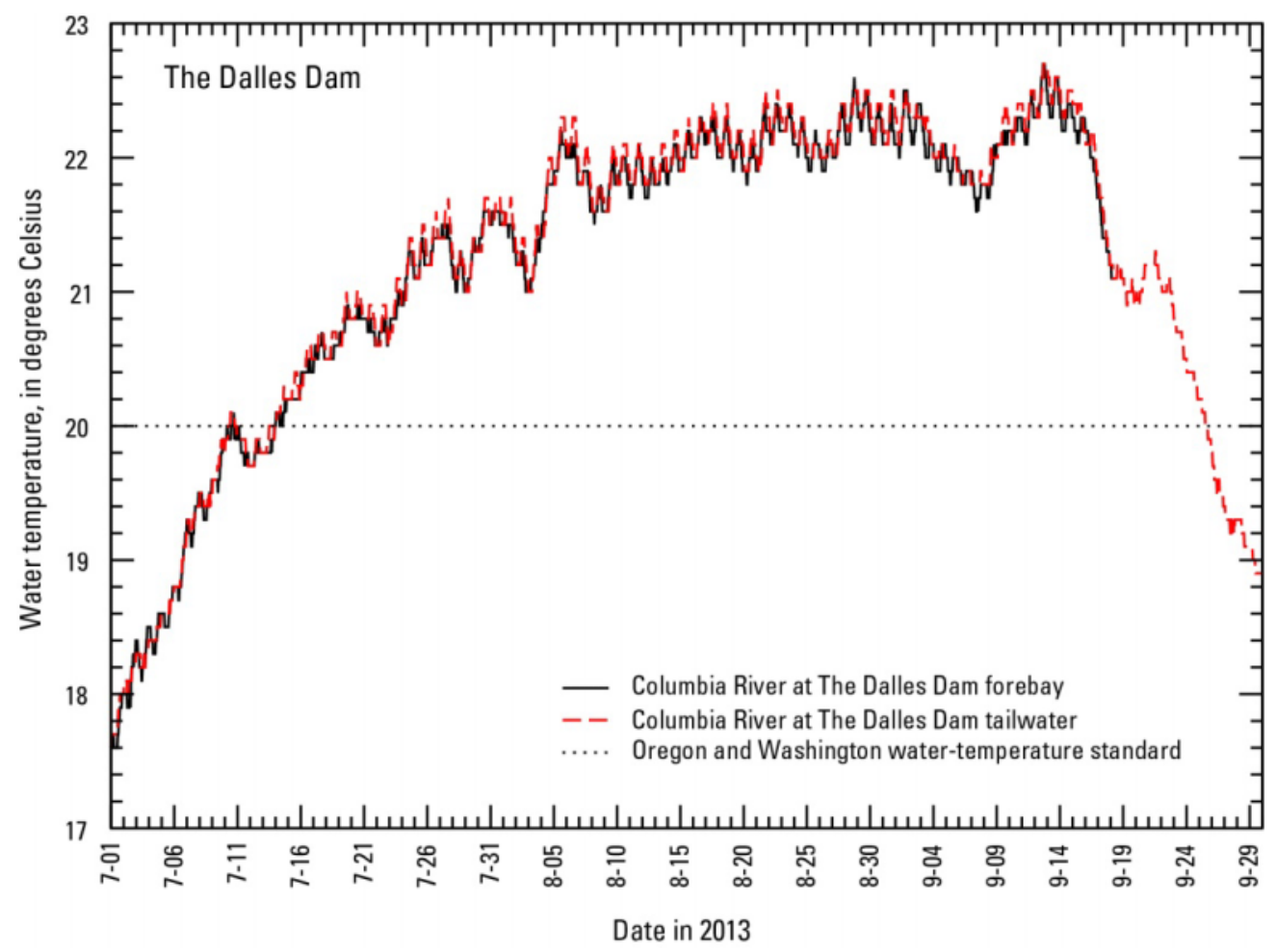

Figure 20. Graph showing water temperature upstream and downstream of The Dalles Dam, lower Columbia River, Oregon and Washington, summer 2013.

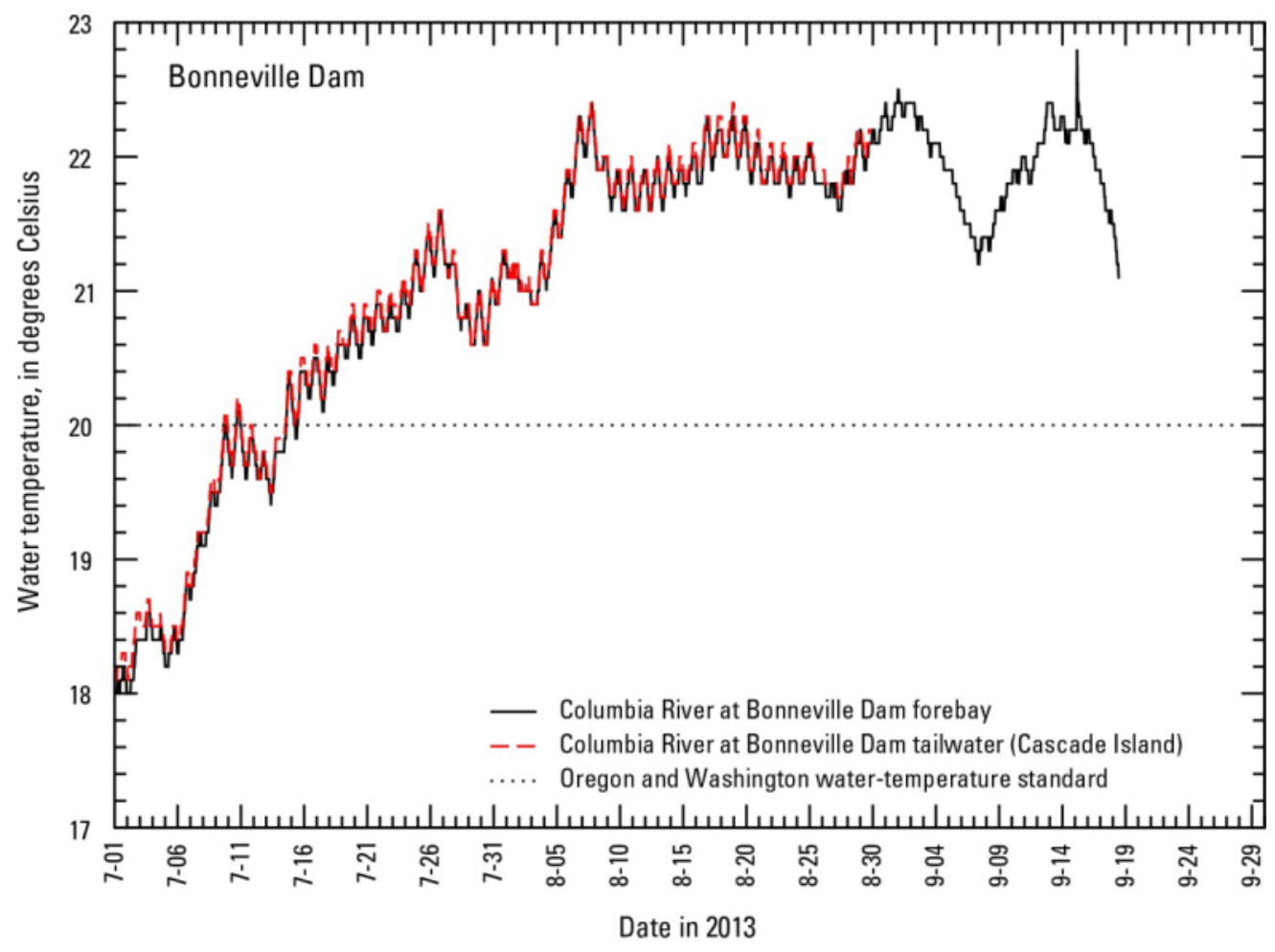

Figure 21. Graph showing water temperature upstream of Bonneville Dam and downstream of Bonneville Dam at Cascade Island, lower Columbia River, Oregon and Washington, summer 2013. 


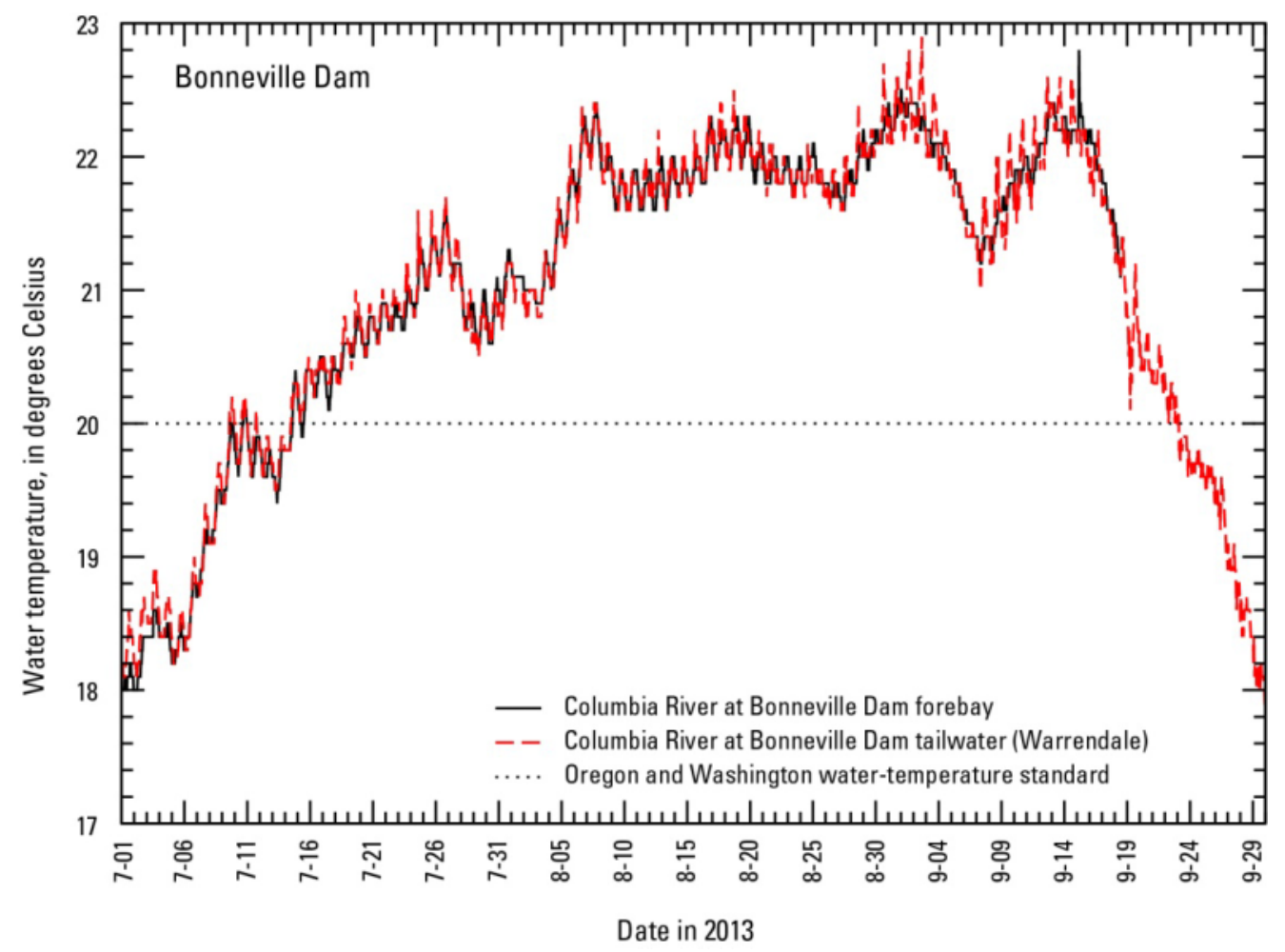

Figure 22. Graph showing water temperature upstream of Bonneville Dam and downstream of Bonneville Dam at Warrendale, lower Columbia River, Oregon and Washington, summer 2013.

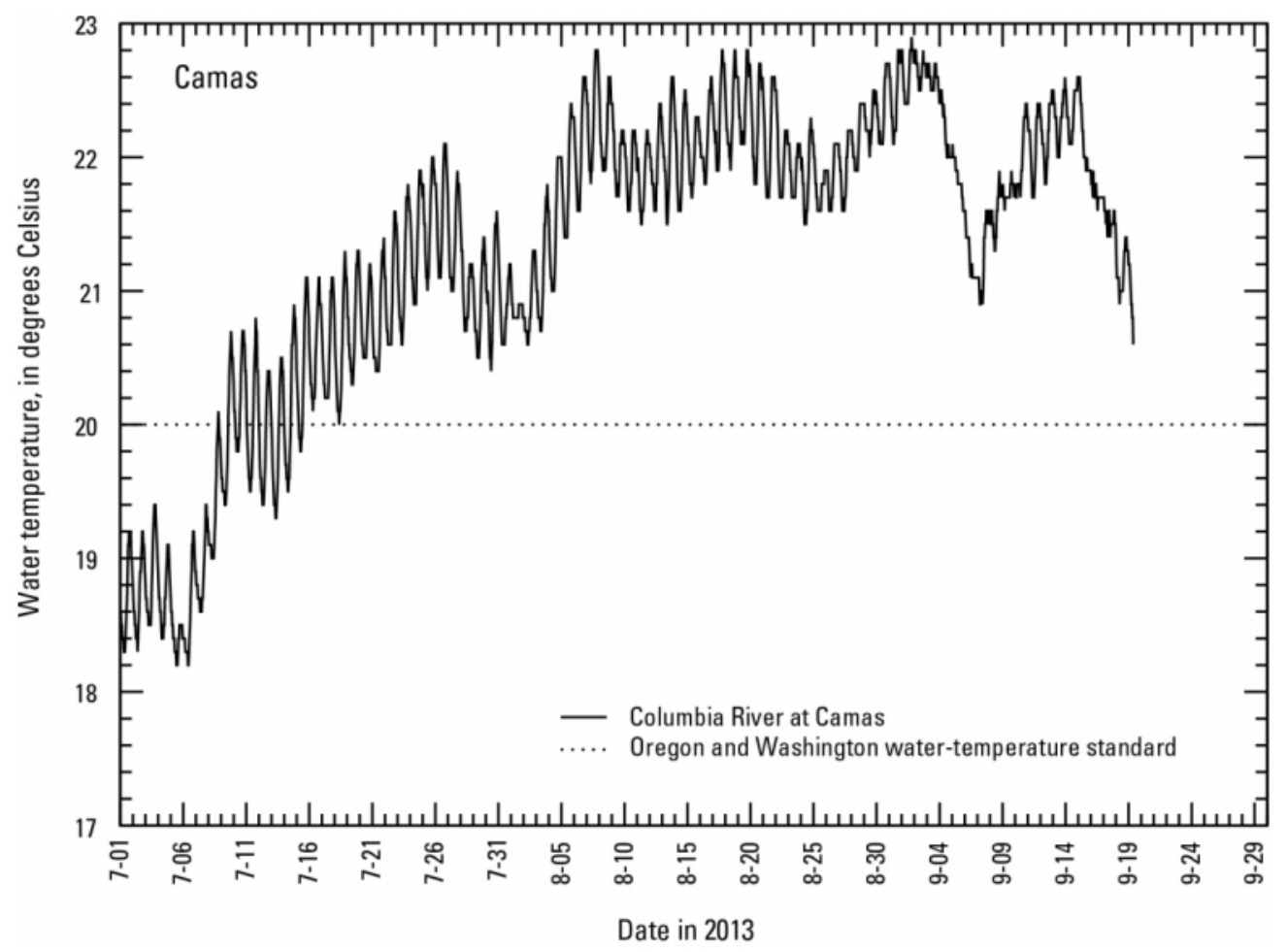

Figure 23. Graph showing water temperature downstream of Bonneville Dam at Camas, lower Columbia River, Oregon and Washington, summer 2013. 


\section{Acknowledgments}

The authors extend special thanks to Tina Lundell (USACE) for technical and logistical support of the project. The authors also thank Amy M. Brooks (USGS) for reviewing the data and Danial Polette for conducting field and laboratory calibration checks.

\section{References Cited}

Colt, J., 1984, Computation of dissolved gas concentrations in water as functions of temperature, salinity, and pressure: American Fisheries Society Special Publication 14, $154 \mathrm{p}$.

Jones, J.C., Tracey, D.C., and Sorensen, F.W., eds., 1991, Operating manual for the U.S. Geological Survey's data-collection system with the Geostationary Operational Environmental Satellite: U.S. Geological Survey Open-File Report 91-99, 237 p. (Available at http://pubs.er.usgs.gov/usgspubs/ofr/ofr9199.)

State of Oregon, 2009, Order approving the U.S. Army Corps of Engineer's request for a waiver to the State's total dissolved gas water quality standard: Oregon Department of Environmental Quality, 4 p., accessed October 31, 2012, at http://www.deq.state.or.us/WQ/TMDLs/docs/co lumbiariver/tdg/

USACEWaiiver2010.pdf

State of Oregon, 2008, Water quality standardsBeneficial uses, policies, and criteria for Oregon: Oregon Department of Environmental Quality, accessed October 31, 2012, at http://arcweb.sos.state.or.us/pages/rules/oars_ 300/oar_340/340_041.html

State of Washington, 2006, Water quality standards for surface waters of the State of Washington, 103 p., accessed October 31, 2012, at http://www.ecy.wa.gov/pubs/wac173201a.pdf

Tanner, D.Q., and Bragg, H.M., 2001, Qualityassurance data, comparison to water-quality standards, and site considerations for total dissolved gas and water temperature, lower
Columbia River, Oregon and Washington, 2001: U.S. Geological Survey WaterResources Investigations Report 2001-4273, 14 p. (Available at http://pubs.er.usgs.gov/usgspubs/wri/wri01427 3.)

Tanner, D.Q., Bragg, H.M., and Johnston, M.W., 2003, Total dissolved gas and water temperature in the Lower Columbia River, Oregon and Washington, 2003-Quality-assurance data and comparison to water-quality standards: U.S. Geological Survey Water-Resources Investigations Report 2003-4306, 24 p.

(Available at http://pubs.er.usgs.gov/usgspubs/wri/wri03430 6.)

Tanner, D.Q., Bragg, H.M., and Johnston, M.W., 2004, Total dissolved gas and water temperature in the Lower Columbia River, Oregon and Washington, 2004-Quality-assurance data and comparison to water-quality standards: U.S. Geological Survey Scientific Investigations Report 2004-5249, 27 p. (Available at http://pubs.er.usgs.gov/usgspubs/sir/sir200452 49.)

Tanner, D.Q., Bragg, H.M., and Johnston, M.W., 2005, Total dissolved gas and water temperature in the Lower Columbia River, Oregon and Washington, 2005-Quality-assurance data and comparison to water-quality standards: U.S. Geological Survey Data Series 148, 31 p. (Available at http://pubs.er.usgs.gov/usgspubs/ds/ds148.)

Tanner, D.Q., Bragg, H.M., and Johnston, M.W., 2006, Total dissolved gas and water temperature in the Lower Columbia River, Oregon and Washington, 2006-Quality-assurance data and comparison to water-quality standards: U.S. Geological Survey Data Series 235, 24 p. (Available at http://pubs.er.usgs.gov/usgspubs/ds/ds235.)

Tanner, D.Q., Bragg, H.M., and Johnston, M.W., 2007, Total dissolved gas and water temperature in the Lower Columbia River, Oregon and Washington, 2007-Quality-assurance data 
and comparison to water-quality standards: U.S. Geological Survey Open-File Report 2007-1408, 23 p. (Available at http://pubs.er.usgs.gov/usgspubs/ofr/ofr200714 08.)

Tanner, D.Q., Bragg, H.M., and Johnston, M.W., 2008, Total dissolved gas and water temperature in the Lower Columbia River, Oregon and Washington, 2008-Quality-assurance data and comparison to water-quality standards: U.S. Geological Survey Open-File Report 2008-1357, 25 p. (Available at http://pubs.er.usgs.gov/usgspubs/ofr/ofr200813 57.)

Tanner, D.Q., Bragg, H.M., and Johnston, M.W., 2009, Total dissolved gas and water temperature in the Lower Columbia River, Oregon and Washington, 2009-Quality-assurance data and comparison to water-quality standards: U.S. Geological Survey Open-File Report 2009-1288, 26 p. (Available at http://pubs.er.usgs.gov/usgspubs/ofr/ofr200812 88.)

Tanner, D.Q., Bragg, H.M., and Johnston, M.W., 2011, Total dissolved gas and water temperature in the Lower Columbia River, Oregon and Washington, 2010 - Quality-assurance data and comparison to water-quality standards: U.S. Geological Survey Open-File Report 2011-1293, 28 p. (Available at http://pubs.usgs.gov/of/2010/1293/.)

Tanner, D.Q., Bragg, H.M., and Johnston, M.W., 2012, Total dissolved gas and water temperature in the lower Columbia River, Oregon and Washington, water year 2011: Qualityassurance data and comparison to water-quality standards: U.S. Geological Survey Open-File Report 2011-1300, 28 p. (Available at http://pubs.usgs.gov/of/2011/1300.)

Tanner, D.Q., Bragg, H.M., and Johnston, M.W., 2013, Total dissolved gas and water temperature in the lower Columbia River, Oregon and Washington, water year 2012-Qualityassurance data and comparison to water-quality standards: U.S. Geological Survey Open-File Report 2012-1256, 26 p.
Tanner, D.Q., Harrison, H.E., and McKenzie, S.W., 1996, Total dissolved gas, barometric pressure, and water temperature data, lower Columbia River, Oregon and Washington, 1996: U.S. Geological Survey Open-File Report 96-662A, 85 p. (Available at http://pubs.er.usgs.gov/usgspubs/ofr/ofr96662 A.)

Tanner, D.Q. and Johnston, M.W., 2001, Datacollection methods, quality-assurance data, and site considerations for total dissolved gas monitoring, lower Columbia River, Oregon and Washington, 2000: U.S. Geological Survey Water-Resources Investigations Report 20014005, 19 p. (Available at http://pubs.er.usgs.gov/usgspubs/wri/wri01400 5.)

Tanner, D.Q., Johnston, M.W., and Bragg, H.M., 2002, Total dissolved gas and water temperature in the Lower Columbia River, Oregon and Washington, 2002-Quality-assurance data and comparison to water-quality standards: U.S. Geological Survey Water-Resources Investigations Report 2002-4283, 12 p. (Available at http://pubs.er.usgs.gov/usgspubs/wri/wri02428 3.)

U.S. Army Corps Of Engineers, 2008, Plan of action for dissolved gas monitoring in 2010 2014: Portland, Oregon, 17 p.

U.S. Army Corps of Engineers, 2012, Total Dissolved Gas Reports: http://www.nwdwc.usace.army.mil/tmt/wcd/tdg/months.html, accessed October 31, 2012.

U.S. Environmental Protection Agency, 1986, Quality criteria for water 1986: U.S. Environmental Protection Agency Publication No. 4405-86-001, accessed October 31, 2012, at http://water.epa.gov/scitech/swguidance/stand ards/criteria/aqlife/upload/2009_01_13_criteri a_goldbook.pdf. 


\section{息}

묭

ํㅡㄹ

우

옹

1

옳

음.

$\frac{\mathrm{O}}{\overleftarrow{\$}}$

ڤึ

气

ISSN 2331-1258 (online)

http://dx.doi.org/10.3133/ofr20131281 